No. 7

ENERO DE 2018

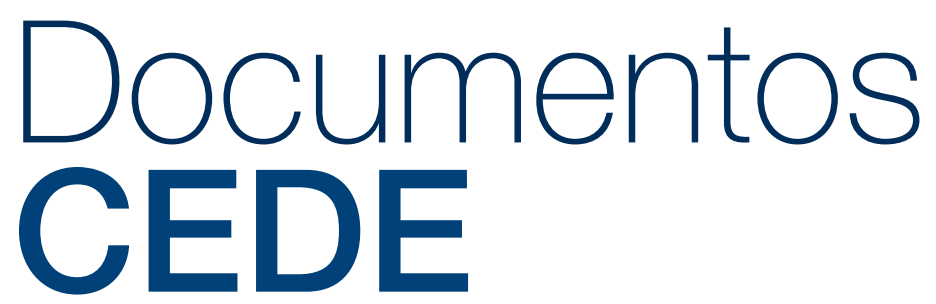

ISSN 1657-7191 Edición electrónica.

Does board diversity affect institutional investor preferences? Evidence from Latin America

María Camila De-La-Hoz

Carlos Pombo

Rodrigo Taborda 


\section{CEDE}

D1)

Facultad de Economía

Serie Documentos Cede, 2018-07

ISSN 1657-7191 Edición electrónica.

Enero 2018

(C) 2018, Universidad de los Andes, Facultad de Economía, CEDE. Calle 19A No. 1 - 37 Este, Bloque W.

Bogotá, D. C., Colombia Teléfonos: 3394949- 3394999, extensiones 2400, 2049, 2467

infocede@uniandes.edu.co

http://economia.uniandes.edu.co

Impreso en Colombia - Printed in Colombia

La serie de Documentos de Trabajo CEDE se circula con propósitos de discusión y divulgación. Los artículos no han sido evaluados por pares ni sujetos a ningún tipo de evaluación formal por parte del equipo de trabajo del CEDE.

El contenido de la presente publicación se encuentra protegido por las normas internacionales y nacionales vigentes sobre propiedad intelectual, por tanto su utilización, reproducción, comunicación pública, transformación, distribución, alquiler, préstamo público e importación, total o parcial, en todo o en parte, en formato impreso, digital o en cualquier formato conocido o por conocer, se encuentran prohibidos, y sólo serán lícitos en la medida en que se cuente con la autorización previa y expresa por escrito del autor o titular. Las limitaciones y excepciones al Derecho de Autor, sólo serán aplicables en la medida en que se den dentro de los denominados Usos Honrados (Fair use), estén previa y expresamente establecidas, no causen un grave e injustificado perjuicio a los intereses legítimos del autor o titular, y no atenten contra la normal explotación de la obra.

Universidad de los Andes | Vigilada Mineducación

Reconocimiento como Universidad: Decreto 1297 del 30 de mayo de 1964. Reconocimiento personería jurídica: Resolución 28 del 23 de febrero de 1949 Minjusticia. 


\title{
Does board diversity affect institutional investor preferences? Evidence from Latin America ${ }^{1}$
}

\author{
Maria Camila De-La-Hoz* Carlos Pombo*+ and Rodrigo Taborda*
}

\begin{abstract}
This paper enquires whether institutional investors have specific preferences on the composition of the board of directors in Latin American firms they hold shares in. The result show that preferences vary significantly in terms of the type of institutional investor. The econometric results suggest grey institutional investors (pension funds and insurance companies) prefer experience and education, while dislike CEO entrenchment. Independent institutional investors value more directors' professional experience i.e., former CEOs and founders of any firm. Grey investors are more concern on firm corporate governance mechanisms consistent with the agency view, while independent investors are focused in business opportunities in accordance with the resource-based-view of board of directors.
\end{abstract}

JEL codes: G10, G11, G34.

Key words: Director Heterogeneity, board capital, institutional investor preferences, Latin America

Acknowledgement. We want to thank the financial support from the Corporate Governance Center at Pontificia Universidad Catolica de Chile that provided financial support from the 2016-annual call.

$1 *$ Universidad de loss Andes School of Management - Finance Department

Emails: cpombo@uniandes.edu.co, r.taborda@uniandes.edu.co and mc.de62@uniandes.edu.co

${ }^{+}$Corresponding author: Carlos Pombo. I want specially thanks Jairo Villamil-Diaz (UNIDO) who grant us access to work the raw dataset of board of directors from his PhD Thesis at the school of Management - Universidad de los Andes that I supervised. 


\title{
¿Afecta la diversidad en juntas directivas las preferencias de los inversionistas institucionales? Evidencia de América Latina ${ }^{2}$
}

\author{
María Camila De-La-Hoz * Carlos Pombo * + y Rodrigo Taborda *
}

\section{Resumen}

\begin{abstract}
Este documento pregunta si los inversionistas institucionales tienen preferencias específicas sobre la composición del consejo de administración en las empresas latinoamericanas en las que tienen acciones. El resultado muestra que las preferencias varían significativamente en términos del tipo de inversionista institucional. Los resultados econométricos sugieren que los inversionistas institucionales grises (fondos de pensiones y compañías de seguros) prefieren la experiencia y la educación, mientras que les desagrada el atrincheramiento del CEO. Los inversionistas institucionales independientes valoran más la experiencia profesional de los directores, es decir, los antiguos miembros de juntas, miembros con experiencia gerencial y fundadores de cualquier organización. Los inversionistas grises están más preocupados por los mecanismos de gobierno corporativo, resultados que son consistentes con el marco analítico de costos de agencia, mientras que los inversionistas independientes se enfocan en las oportunidades de negocios de acuerdo con el marco conceptual de disponibilidad de recursos.
\end{abstract}

Códigos JEL: G10, G11, G34.

Palabras clave: Heterogeneidad del director, capital de la junta, preferencias de inversionistas institucionales, América Latina

Reconocimiento. Queremos agradecer el apoyo financiero del Centro de Gobierno Corporativo de la Pontificia Universidad Católica de Chile que brindó apoyo financiero de la convocatoria anual de 2016.

\footnotetext{
2 * Universidad de los Andes, Área de Finanzas, Facultad de Administración. Emails:.cpombo@uniandes.edu.co, r.taborda@uniandes.edu.co and mc.de62@uniandes.edu.co

+ Autor de contacto: Carlos Pombo.
} 


\section{Introduction}

During the last 20 years, the number of institutional investors has grown substantially in developed economies such as Canada, the United States and the United Kingdom and they now control more than half of the corporate property in these countries (Aggarwal et al., 2010). According to Ferreira and Matos (2008), the increasing importance of institutional investors is a key factor in the global capital market, suggesting that the presence of these investors is vital financial markets development. In Latin America, institutional investors have a real opportunity to influence the development of the region's capital markets, since they currently manage considerable financial assets (Blume and Alonso, 2007). Many studies on institutional investors have analyzed the relationship between performance, firm valuation and ownership structure (Del Guercio and Hawkins, 1999; Woidtke, 2002; Navissi and Naiker, 2006, Ferreira and Matos, 2008; De-La-Hoz and Pombo, 2016) concluding that firms with institutional blockholders are associated with higher firm performance and value yield stocks. These studies derive their results based on market performance while firm internal corporate governance mechanisms, those related with the board of directors, are not considered to understand the presence and extent of institutional investors.

Given the potential benefits derived from institutional investors in emerging markets, understanding the institutional investors' preferences is a must. In this study institutional investor preferences are examined in connection with the composition of the board of directors and director characteristics. The resource base view of boards stresses that board members qualifications and skills became an important strategic resource for the firm, links the firm to external resources, providing a network to a nation's business elite, access to capital, market intelligence, and information from the competition. The board is also seen as a complement of 
shareholder and market monitoring since it limits managers' discretion to engage in opportunistic behavior (Jensen, 1993; Shleifer and Vishny, 1997; Walsh and Seward, 1990). As a consequence, the board is said to embody the routinization of shareholders' distrust (O'Connell and Teo, 2009), which helps to explain why it can be relevant and key factor in explaining the entry and permanence of institutional owners.

The behavior of institutional investors and their preferences on board characteristics is an understudied problem. The aim of this study is to enquire whether institutional investors have preferences on the composition of the firms' board of directors they invest in, in markets with low investor protection levels. The empirical approach to answer this question resorts on factor analysis, which reduces the multiple dimensions of board of directors characteristics, and regression analysis to determine how such factors do explain the presence and extent of institutional investors. Presence of institutional investors is studied in a probit regression, while shareholdings is explored using panel data regression methods. This is one of the first papers that tests institutional investors’ preferences on boards across a representative emerging market region such as Latin America.

The contribution of this study to emerging markets finance literature, relies in providing empirical evidence that board structure and director backgrounds are linked to institutional investors that provide internal corporate governance mechanisms. More qualified boards enhance efficient monitoring, reduces agency cost for shareholders, provide qualified counseling for firm top executives regarding financial and corporate strategy decisions. Institutional investors take for granted this information in deciding whether to provide equity financing. Qualified boards constitute a hedging mechanism for investor protection in markets with limited law compliance and accountability. 
The results of this study show that the presence of institutional ownership as blockholders increases with directors' education and experience. The estimations shows there are different preferences according to investor colors. In line with the agency view that minimizes agency costs for shareholders, grey investor value characteristics and structures related with better director monitoring - blockholder voice -, such as independent directors, diverse boards with higher number of female and foreign directors, and directors with a master's degree.

Independent investors by contrast show clear preferences for factors associated with directors' relational capital that enhances business opportunities, such as directors' background as entrepreneurs, but at the same time they dislike directors with professional experience within the public sector.

This study extend previous work on institutional investors preferences in focusing on director characteristics and board structures driving factors in explaining institutional blockholder ownership entry permanence and their shareholdings. Previous related work on board diversity evaluates mainly gender diversification and its effects on firm ex-post market values (Adams and Ferreira, 2009) for listed firms belonging to S\&P and Rusell’s indices. From financial management view the study of Anderson et al. (2011) analyze what explains the demand for diverse boards. Their main findings suggests that operational complex firms (i.e., large, indebted, multiproduct firms with high fixed costs) demand more heterogeneous boards.

Studies on the determinants of institutional ownership with world wide data analyze what type of companies institutional investors invest in, such as large, cross listed, and dividend yield firms. Also, they invest in firms with a good corporate governance reputation, with foreign investor or institutional shareholders (Ferreira and Matos, 2008). Studies on the corporate governance preferences of large and long term institutional investors based in the U.S. with 
international portfolios support that the voice versus exit models become complementary mechanisms as governance device to discipline firm management (McCahery et al., 2016).

The remainder of the paper is organized as follows. Section 2 reviews the literature in board composition, diversity and develops the hypothesis herein explored. Section 3 presents the data characteristics. Section 4 outlines the factor analysis procedure. Section 5 presents the econometric results and the robustness analysis. Section 6 concludes.

\section{Theoretical Framework and hypotheses formulation}

This paper asks how board composition and director characteristics are related to presence and ownership of institutional investors. The theoretical framework comes from two related research lines in corporate finance and organizational studies literature: i) institutional investor preferences; and ii) board of directors' diversity. Both sets of empirical studies are mostly related with firm value and performance.

\subsection{Institutional investor preferences}

Empirical research on institutional ownership has highlighted their influence on firm-level corporate governance practices and their role in reducing agency costs between firm insiders and outsiders capital providers. Institutional investors potentially influence firms to adopt better governance practices, either directly, by assuming the costs of exerting direct management monitoring -voice models- (Hisrhman, 1970), or indirectly, by trading their shares (Edmans and Manso, 2011). Results suggests that institutional investors are less likely to invest in firms with poor corporate governance structures subject to cash flow tunnelling, and that reside in countries with opaque disclosure measures and investor protection levels (Leuz et al., 2009). 
Gompers and Metrick (2001) find that institutional investors privilege companies with larger market capitalization, higher liquidity and higher book-to-market ratio, compared to individual investors. Bushee et al. (2014) report that around 10\% of institutional investors are governancesensitive and exhibit strong correlations between institutional holdings or portfolio weighting and firms' governance mechanisms. They also find that firms with a high level of institutional ownership sensitive to shareholder rights exhibit significant future improvements in shareholder rights, implying some activism by these institutions.

Aggarwal et al. (2005) analyse the preferences of US mutual funds with investments in emerging markets. After controlling for the country's level of economic development, they found that firms in countries with stronger shareholder rights and legal frameworks attract more foreign capital. At firm level, they found that mutual funds invest in large firms and firms covered by a larger number of analysts as well as firms with high returns and leverage. They found that the quality of accounting disclosure was also crucial, while stock liquidity was not significant. Given the above, authors concluded that the accounting standards of a firm become very important in countries without strong shareholder rights. In a follow up paper Aggarwal et al. (2011) study the role of international institutional investment as a channel for promoting better corporate practices at firm level. Based on an international panel dataset of more than 2000 non-US firms belonging to 22 OECD countries, they find that changes on institutional investor ownership foster changes at firm level corporate governance (CG).

Institutional investor heterogeneity implies the existence of different interests and preferences over their investment portfolios. Institutional independent investors tend to monitor more actively because they have less natural potential for business relations with the corporations. Almazán et al. (2005) call them active investors while Brickley et al. (1988), call them "pressure-resistant" 
investors. Ferreira and Matos (2008), analyse institutional investor heterogeneity by contrasting different types of groups. One criteria is coding institutional ownership by their monitoring role as independent (i.e., investment funds and banks) and grey investors (i.e., bank trusts, insurance companies and pension funds) or by geographical origin domestic and foreign investors. Ferreira and Matos work with an average sample of 4,116 large institutional investors from 24 OECD economies and 3 large emerging markets for 2000-2005. Around 65\% of institutions in the sample are US-based investors. Their main findings are that institutional investors invest more in large firms, and in firms with a good corporate governance reputation; foreign investor institutions value cross listed firms in the U.S and firms that exhibit high foreign and independent institutional investor equity holdings show higher market valuations, better operational performance, and lower capital expenditure.

Investor activism implies an investor behaviour in engaging in forward looking monitoring that will cause an effect on different corporate policy such as pay-out policy (i.e., clientele effect), investment, leverage policies as well as corporate best practices as the finding results of above mentioned studies suggest. However, investor preferences about their mode of intervention is undisclosed and unobservable. McCahery et al. (2016) conduct a direct approach to analyze institutional investors' preferences through a survey of institutional investors with long term focus enquiring about corporate governance from a country and firm perspective. They find that institutional investors consider among the most important characteristics, equity ownership of management, use of equity based compensation, board independence, transparency about the holdings of large shareholders, and high free float ${ }^{3}$.

\footnotetext{
${ }^{3}$ A high free float allows firms to liquidate shares easily, allows prices to more accurately reflect managerial effort and thereby increase the efficiency of stock-based compensation (Holmstrom and Tirole, 1993; Edmans, 2009), and suggests lower holdings of large shareholders and therefore lower agency problems between large and small shareholders (McCahery et al., 2016).
} 
Bushee et al. (2013) find that investors with preferences for growth, lean their portfolios toward firms with "better" board characteristics, implying that investors view board governance as more crucial for firms with a high level of growth opportunities. On the other hand, the authors find that investors with long investment horizons are more likely to lean their portfolios toward firms with "better" shareholder rights, suggesting that shareholder governance allows these investors to protect their large, stable investments. The criteria when deciding where to invest, varies dramatically within pension funds institutions. Case studies for the U.S has shown that some pension funds are either performance or governance oriented ${ }^{4}$.

Overall, the results of the above mentioned studies suggest that institutional investors focus primarily on issues that reduce agency conflicts and that firms located in countries with weak legal regimes may be able to attract investors with stronger corporate governance mechanisms and clearly provide evidence that institutional investors care for firm characteristics inherently related factors that have an effect of firm level corporate governance such as the structure of boards and directors’ characteristics, stock liquidity and trading, ownership structure and managerial compensation. The theoretical work and the empirical evidence of those studies lead us to state the following hypothesis:

H1: Firm corporate governance observable drivers like board structure and directors' characteristics are linked to institutional ownership presence and the size of their shareholdings.

Hence, internal firm level corporate governance mechanisms becomes central for investor protection and reducing the risk for expropriation in countries ranked with poor corporate governance standards such as Latin America.

\footnotetext{
${ }^{4}$ For more details the studies of Whal (1996) and Carlenton et al (1998)
} 


\subsection{Director heterogeneity and board capital}

Corporate finance empirical research on board composition and firm performance has mostly relied on the agency view (monitoring role) in explaining the ex-post effects that a given structure has on firm market value and the providing the mechanisms for an effective investor's protection. The main findings over the last decade have shown that board independence has had positive effects shareholder's returns on those firms that have adopted corporate governance standards, for instance the Cadbury Report in the UK, or outside directors have a positive effect on firms Tobin’s Q for the case of Korea. ${ }^{5}$

The resource based view on the other hand has a long tradition within organizational theory (Pfeffer and Salancik, 1978, Hillman, et al., 2000), which provides a complementary analytical framework to the agency view (voice models) regarding director diversity as a means to bring resources to firms that those individuals serve, as board members. In that sense, boards as a cohesive body is the sum of members' skills, knowledge, experience, reputation, education levels and cultural backgrounds that define a concept of board capital as a firm input that might benefits shareholders rights in providing more effective monitoring and counseling to firms top management. In addition, they can generate economic spillovers to firms in their access to external financing, new contracts for public bidding, attract new investors and open product markets through their networks and its signaling to investors of company's strong corporate governance.

Resource based view defines board capital as the sum of human capital (e.g., education) and relational capital (e.g., director's networking, connections and professional experience) becomes an organizational input that affects firm performance through the resources provided by corporate directors. Hillman and Daziel (2003) study how provision of resources of diverse boards bring to

\footnotetext{
${ }^{5}$ For more details see Dahya and McConnell (2007), Choi et al., (2007), Black and Kim (2012).
} 
firms effective counseling and advising, firm legitimacy, tangible resources, and channels of communications enhance firm performance. They also propose an integrative model of agency and resource views stating that given a board capital supported by diverse boards, directors incentives determine to exert more (less) monitoring and provide more (less) resources to the firms they oversight and advise and therefore have more (less) impact on firm performance. Figure 1 illustrates the moderating role that incentives (e.g., directors' compensation schemes) have on directors monitoring and provision of resources and therefore will impact in a greater/lesser degree firm ex-post performance and therefore . The key assumption underlined by Hillamn and Daziel (2003) framework is that capital board components - diversity drivers- are exogenous or fixed in the short run. This means that directors' appointments with the desired characteristics, be they outsiders or insiders, is binding by the market of directors. This feature is more evident within emerging markets where directorate diversification is lower because most listed firms are affiliated to business groups, firms face family control and corporate ownership follows multiple blockholder structures.

\section{[FIGURE 1 HERE]}

The concept of board capital implies the existence of economic spillovers upon firms' corporate policies access to external finance and markets through directors' connections and professional reputation; and in general attract new investors. Higher board capital becomes a market signal of strong internal corporate governance.

The empirical evidence of board heterogeneity suggest a positive effects on firm value. For instance, the study of Anderson et al. (2011) based on sample of 615 industrial firm in the U.S. that belong to the Russell 1000 index find that operational complex firms (i.e., large, indebted, multiproduct firms with high fixed costs) demand more heterogeneous boards. They find that $10 \%$ 
change in the board diversity index then the adjusted Tobin's Q will change by $7.8 \%$. In addition, controlling by firm operational complexity index this effect reduces to changes in firm value by $3.2 \%$.

Studies regarding directors' educational level and financial experience stresses the benefits for firm risk management. Dionne et al. (2013) assess whether boards with high fraction of financial knowledgeable directors foster the use of derivate contracts as firm hedging strategy. Their results based on a sample of 348 gold mining firms, suggest that directors with formal financial education (i.e., MBAs, BBA, MSc Finance) encourage the use of derivatives for firm risk exposure in their investments and portfolio activities. Hedging foster firm value and reduces firm cost of capital which increases shareholders value. ${ }^{6}$ A related and more recent study on directors' background, Wang et al. (2016) analyze how the professional profiles of independent directors in Chinese state-owned enterprises influence corporate performance. Their main result support positive correlation for firm operating liquidity - cash holdings- from independent directors that come from either academic institutions, accounting firms or foreign investment enterprises.

Based on the above analytical rationale and finding the next working hypothesis follows:

H2. The higher board capital, provided by directorate diversity skills, the higher the presence of institutional investors and their holdings.

The transmission mechanism implicit in $\mathrm{H} 2$ is that greater board diversity improves the efficiency in monitoring and counseling to management, ultimately benefiting shareholders.

\subsection{Costs of board diversity}

Organizational literature has also highlighted potential costs of board diversity associated with several potential conflicts inside directorates such as communication breakdowns, members'

\footnotetext{
${ }^{6}$ See for instance, Campello et al (2011)
} 
conflict of interest and choosing the wrong profiles to comply only with a gender or minority quota within boards.

Adams and Ferreira (2007) analyze theoretically the tradeoffs between executive and nonexecute directors regarding the directors' role of monitoring versus counseling. In that sense a CEO knows that as long that he discloses more information will get better advise but at the same time will face tougher monitoring particularly from outside directors. The equilibrium strategy from their model will imply that dominant shareholders will choose friendly members in order to get more counseling and less monitoring. Hence, friendly board might constitute an optimal structure.

Political connected directors have been studied within financial institutions. These types of directors might have their own agenda and engage in rent seeking behavior, exhibiting clear conflict of interests. Braun and Raddat (2010) show empirically that banks around the world (i.e., more than 100 countries) with political connected directors exhibit grater return on assets. Those depositary institutions are large, less leveraged and exhibit better performing loans ratios lowering overall bank's credit risk. At macroeconomic level they find that countries with high political connected boards within commercial banks exhibit and inverse correlation with country's financial development.

Research on board gender diversification during the last decade casts doubt on the positive effect of gender diversification on firm ex-post market value. Adams and Ferreira (2009) analyze the causality between gender diversity and firm Tobin's Q based on a sample of more than 1,900 listed firms in the U.S. S\&P 500 between 1996 and 2003. They report that the observed correlation between these variables is driven by an omitted variables bias, such as corporate culture. After controlling for firm fixed effects they report a conditional negative correlation $(\beta=-0.13 ; t=$ 1.67) between the fraction of female directors and the log of Tobin's $Q$. 
Parallel studies on board gender have also covered the case of mandatory minority quotas analyzing the Norwegian case. The gender law of 2003 enforces a 40\% female in boardrooms within listed firms. Ahern and Dittmar (2012) analyze the impact of firm valuation in Norway explained by the enforcement of female quota policy. They find that in 2008, the date of full law compliance, a 10\% increase in the fraction of female directors decreases Tobin's Q (industry adjusted) by -0.19 points with respect to overall firm-year average Q.

The above arguments and results regarding the costs of board diversity implies that there is a non-linear relationship between board capital components to firm value, and therefore investors have different preferences on director heterogeneity. Thus, the following hypothesis follows

H3: Different types of institutional investors have different preferences on director heterogeneity and diversify boards.

Hence, H3 implies that institutional investor types have different preferences on monitoring mechanisms versus resources opportunities associated to board capital and therefore they will value differently board human and relational capital elements.

\section{Data sample, dependent and board variables}

\subsection{Sample construction}

This study uses a longitudinal database from 2001 to 2011 for 439 non-financial firms from Latin American countries: Argentina, Brazil, Chile, Colombia, Mexico and Peru, accounting for 4,399 firm-year observations. The major source of the financial and ownership (blockholders) data was Thomson's Datastream platform (Thomson Reuters Datastream, 2013). Information from financial regulators in each country was also used, as well as annual reports of each firm. Shareholder information for Chile, Brazil and Peru, was extracted from Economatica (2013) and 
the corresponding local regulatory agencies. ${ }^{7}$ The main source of data on board of directors (such as: gender, educational, background, experience, etc.), was Thomson One (2013), and handcollected biographical information. Table 1 summarizes the construction of the sample and its representativeness. Data extraction began with 4,809 firms. After removing non-active firms, firms with non-equity instruments, financial firms, and those with missing financial or board of directors' information, the number of firms under scrutiny is 439 .

\section{[TABLE 1 HERE]}

\subsection{Institutional ownership, board structure and director related variables}

This study defines an institutional investor as the one who is either an investment fund, a bank, a pension fund or an insurance company among the top three shareholders. A major concern about institutional investor's variables is related to the endogeneity related with the investor preferences. Generally, it is likely that institutional investors flock their diversified portfolios to firms that already have good corporate governance, and, therefore, lower cost of external resources and less agency costs as discussed in the previous section. In order to attenuate the investor's preferences for firms with good governance, we only consider those institutional investors that than can be identified as blockholder who own at least $5 \%$ of firm cash flow rights. This definition should be helpful in removing low compromised investors only interested in extracting benefits from an already existing governance structure. Following Ferreira and Matos (2008), institutional investors were classified into two distinct groups according to their monitoring role: independent investors (investment funds and banks) and grey investors

\footnotetext{
${ }^{7}$ Superintendencia de Valores y Seguros (Chile), Superintendencia del Mercado de Valores (Peru), Comissao de Valores Mobiliarios (Brazil), Superintendencia Financiera (Colombia). Comision Nacional Bancaria y de Valores (Mexico), and Comision Nacional de Valores (Argentina).
} 
(insurance companies and pension funds). Investor heterogeneity presence and their shareholdings follow the same criteria used for total institutional ownership.

Boards of directors' variables are the ones of interest in this study since they constitute the sources of a firm's board capital to test the main study's hypotheses. We split the variables in two sets. One that gives account of the board as a whole, and one that highlights the members profiles. The board structure variables are: board size, outside members, board turnover, inside directors, a dummy variable if the CEO is a board member, and a dummy variable indicating if the CEO is chairman of the board. These variables give account of the choices made by the firm itself in the configuration of its board of directors and their corporate governance compliance according to country’s specific regulation to security issuers.

Board individual characteristics variables on the other hand show member's experience, educational background and director diversity. The chosen variables are: age, female and foreign director participation, directors with master's degree, undergraduate studies different from law or business; directors with managerial, entrepreneurial and with public sector backgrounds. All non-dummy variables are normalized with respect to board size. ${ }^{8}$

Table 2 displays the summary of statistics for institutional ownership the board related variables. Several comments are worth highlighting. The statistics in panel A shows that in 57\% of the sample firms have at least one institutional investor as blockholder with $22 \%$ of equity share on average. Independent blockholder investors are present 54\% in total sample, while grey investors are in 11\%. This structure in institutional ownership in Latin America is similar to what has been traced for other larger emerging economies (Alvarez et. al., 2017).

\footnotetext{
${ }^{8}$ Complete definitions and their sources are in the appendix (Table A.1)
} 
Regarding board variables panel B shows that the mean of board size is 10 members, outside members are more than 7 individuals, but the independent ones are less than two. In around 20\% of the sample the CEO is also the chairman of the board, and in $11 \%$ of board members have been past firms' CEOs. Panel C displays director characteristics variables. In particular, the mean age is 52 years, $32 \%$ of directors have experience as managers, but only $4 \%$ of those members have been founder partners of companies or report labor experience within the public sector. Educational background show that $28 \%$ of board members have a degree in business studies at bachelor level, and 23\% have a master degree, including MBAs.

\section{[TABLE 2 HERE]}

\section{Method}

\subsection{Empirical baseline equation}

The main focus of the empirical strategy is to analyze the association that firm board capital has on institutional ownership presence and the amount they have invested in. Investor preferences are influenced by firm board capital in terms of human and relational capital of their members, because they are signals of firm corporate governance and investor protection levels, and valuation opportunities to their portfolio allocations.

The empirical approach to investigate those relations is through two baseline econometric specifications. The first models institutional investor presence through a discrete dependent variable capturing whether an institutional investor is within the top three blockholders. The second models institutional investor equity shares as dependent variable.

Regressions follow a general two-way error component model that includes industry and country fixed effects, that is: 


$$
\begin{aligned}
\mathbf{I I}_{\mathbf{i}, \mathbf{t}}= & \beta_{0}+\beta_{k} \mathbf{B D I V}_{\mathbf{i t}}+\delta_{k} \mathbf{B S}_{\mathbf{i t}}+\gamma_{k} \mathbf{O W N}_{\mathbf{i t}}+\varphi_{k} \mathbf{X}_{\mathbf{i t}}+\beta_{j} \mathbf{M A C R O}_{\mathbf{j t}}+\beta_{l} \mathbf{I}_{l}+\beta_{j} \boldsymbol{c}_{j}+\left(u_{i t}+\right. \\
& \left.\lambda_{\mathbf{t}}+\varepsilon_{i t}\right) \quad(1)
\end{aligned}
$$

where subscripts i stand for firm, $\mathrm{l}$ for industry, $\mathrm{j}$ for country, and $\mathrm{t}$ for year. The dependent variable (II) is either the dummy for institutional investor presence or shareholdings. Board diversity (BDIV) in equation (1) models the link between corporate board diversity variables and institutional ownership (), controlling by a set of internal corporate governance variables that includes board structure (BS), blockholder's contestability ownership variables (OWN), firm financial specific variables (X) and country institutional and macroeconomic variables (MACRO).

\subsection{Factor analysis}

We relied on factor analysis to reduce the dimension of board variables into more meaningful theoretical concepts related with board structure as a whole and director's individual characteristics. Factor analysis accomplishes the purpose of reducing several variables into theoretically relevant concepts explaining the characteristics of board of directors without losing information, and avoiding collinearity issues. The undertaken factor analysis resorts on principal component analysis with factor loading rotation.

Table 3 displays the rotated (orthogonal) factor loadings for each one of the analyzed variables. Factor analysis around variables comprising information on board structure (panel A) suggested to retain the first two factors (those factors with eigenvalue higher than 1 in the principal components analysis) explaining $68 \%$ of the variance. The first factor has a high negative loading in the outsider variable and high and positive loading in the employee variable. CEO on the board of directors and $\mathrm{CEO}$ as chairman of the board (COB) also have a positive loading. Given such loadings factor 1 mostly summarizes a board which welcomes existing employees and 
dislike alien members, in line with this interpretation the factor is labeled as "Board Factor: Entrenchment”. Factor 2 loadings shows a higher positive role from the CEO and negative from the turnover rate. This factor unveils the role of CEO and the dislike for volatility, this factor is labeled as "Board Factor: CEO \& stability”.

Factor analysis that incorporates board members characteristics (panel B), suggest to retain the first three factors (those with eigenvalue higher than 1 in the principal components analysis) which explained 52\% of the variance. For the set of included variables we see that factor 1 gives positive loadings to directors with Masters' degree and bachelor in non-business and law. This factor is labeled as “People Factor: Education”. In the same way factor 2 exhibits high loadings on director's professional backgrounds - experience as CEO, founder of firms, experience within the public sector - This factor is labeled as "People Factor: Experience". The third factor has largest weights on director diversity by gender and nationality. This factor is labeled as ““”People Factor: Diversity”. Panel C summarizes the statistics of the factor scores (linear regression prediction) measured in standard deviations from their means.

\section{[TABLE 3 HERE]}

\subsection{Control variables.}

The set of control variables in the baseline equation 1 includes firm specific blockholder control contestability proxies and financial variables. The country institutional and macroeconomic variables complete the set of controls. In line with empirical research on firm value and blockholder contestability (Maury and Pajuste, 2006, Leaven and Levine, 2008, Jara-Bertín et al. 2008, and Pombo and Taborda, 2017), we include four blockholder ownership indicators in the empirical model. The first of these is the Herfindahl index, a standard indicator for ownership concentration. The second is the fraction of equity shares of the second blockholders. Recent 
studies have shown a positive effect on firm Tobin's Q when a second blockholder has enough power to control the largest one when he or she does not have absolute control (i.e. equity rights lower than 0.5).

The third indicator is the Shapley coalitional value, which is the solution for cooperative games. We followed the definition of oceanic finite games to compute power indices proposed by Leech (2002). The Shapley value measures the probability of the largest shareholder forming a coalition with either of the two next largest shareholders. The Shapley value is 1 for all firms where the largest shareholder has more than $50 \%$ of the firm's equity rights. The fourth indicator is the Wedge between control and cash flow rights of the largest shareholder hat usually is the controlling shareholder. This variable is a proxy for potential tunneling and cash flow diversion. We measure blockholder wedge as the ratio of Shapley value to cash flow rights. This is an indirect measure when data on cross-ownership and pyramidal structures are incomplete (Guedes and Loureiro, 2006). We followed this definition because of data availability. ${ }^{9}$

Firm financial-specific variables included in the model are Return on Assets (ROA), leverage, operating income volatility, firm size, firm stock beta, asset tangibility and stock turnover. Return on assets (ROA) is used as a measure of firm performance, this variable is defined as the net income to total assets ratio. Operating income volatility is measured as the standard deviation of operating income for the last three year. This variable serves as a proxy for firm idiosyncratic risk. Other things being equal, the higher a firm’s operating income volatility, the lower the likelihood an institutional investor will be present. Firm size, is measured by the natural logarithm of total assets. A negative relationship between size and the presence of

\footnotetext{
${ }^{9}$ Wedge is usually measured as is the percentage of votes controlled by the firm's largest shareholder minus the percentage of cash flow rights owned by the firm's largest shareholder. This definition implies using observed data to measure a shareholder's voting rights trough the weakest link within the ownership chain (Claessens et al., 2002).
} 
institutional investors is expected, since size proxies for firm age, and older firms tend to be less dynamic. It is also a proxy for the possibility of moral hazard from management, since monitoring costs increase with size. Stock Beta is the standard measure of systemic risk for a firm's stock with respect to the market. It measures shares that have been traded for more than 180 days in a given year. Asset tangibility stands for as plant, property and equipment valuation relative to the total assets ratio. Low asset tangibility signals that a firm's cash flow is being produced by intangibles. Stock turnover, as a proxy for market liquidity, is a dummy variable that takes the value of one if the stock turnover of the firm is above the 75 th percentile. $^{10}$

The equation also includes macroeconomic variables as controls. These are the emerging markets bond index (EMBI) as proxy of country risk, market capitalization ratio as indicator of stock market deepening and the property rights index that captures country investor protection levels. We expect a negative relation between institutional ownership and the EMBI index, and a positive relation with the last two macro variables.

\section{Econometric results}

\subsection{Institutional investor presence}

This section presents the estimation results for the institutional blockholder presence. The regression equations model the link between factor analysis variables presented in the previous section and institutional investor presence using a limited dependent variable (probit) estimation. Table 4 summarizes the core results. First, on average institutional investor's presences can be explained by directors' education, regardless their

\footnotetext{
${ }^{10}$ Complete variable definitions and their sources for all variables included in the econometric estimates and the descriptive statistics of all control variables are in appendix (Tables A1 and A2).
} 
relative direct activism (monitoring) upon firm management, whether they are independent or grey investors. The marginal effect is 0.14 for grey investors, while it is 0.08 for the independent ones. This means that a change in 1 standard deviation on the education factor score will increase the probability of institutional owner presence by $14 \%$ and $8 \%$ respectively ${ }^{11}$. Second, Grey investors value positively director experience. Its marginal effect is 0.13 , while Independent investors assign a negative value to director composite experience as a whole, decreasing their presence by $-14 \%$. These findings suggest that overall institutional investors cares about controlling agency costs through more educated directors. However, grey investors such as pension funds are more concerned about director's relational capital than their professional peers (mutual funds, investment firms). The above regression coefficients are significant at $5 \%$ level while the diversity factor score is not statistically significant. Neither independent nor grey investors show a strong preference for board diversity in terms of gender of nationality distributions.

Third, board structure factor scores are important for the presence of grey investors. They dislike entrenched boards without a clear separation, whether the CEO is on the board or boards with high fraction of inside (executives) directors. Further, regarding board factor stability, grey investors prefer boards with clear turnovers and less stability in time of their members especially for CEOs with duality appointment as directorate’s COB (Col.4). Board turnover become a disciplinary mechanism for shareholders’ stewardship.

Regarding the control variables institutional ownership presence is positive related with wedge between ownership and control for the total sample. The marginal effect is 0.11 (Col.2), meaning that 1 standard deviation change [0.33] in the difference between voting to cash flow

\footnotetext{
${ }^{11}$ Rotated factor scores are linear composites formed by standardized each variable of zero mean and unit variance, as shown in Table 3.
} 
rights will increase the probability of institutional ownership presence by 0.036 . This outcome suggest that they seek to enhance their voting power through the potential excess of control. The risk of potential tunneling and self-dealing transactions is for minorities and not for blockholders.

Firm specific controls show partial evidence on the direction of institutional investor preferences regrading firm size, leverage, return on assets, and stock turnover among other explanatory variables. Results show for instance that independent investors prefer small and less leveraged firms. Nonetheless, grey investors prefer large firms. Asset tangibility as proxy of firm collateral affects positively the presence of institutional blockholders. The above coefficients are significant at 5\% level. The macroeconomic variables in contrast do not show a clear and statistically significant effect on institutional blockholder ownership dummy. Figure 2 shows the predicted probabilities for grey and independent institutional investors using the factor loads score indices as explanatory variables from the probit model.

\section{[TABLE 4 AND FIGURE 2 HERE]}

Table 5 replicates the probit model but taking into account individual variables of board diversity and structure in order to complement the baseline equations based on factor analysis. Looking at the components of board diversity and structure help to shed light on the specific size effect that those variables have on institutional ownership presence. Four main comments arise from the table. First, there is a positive and robust effect of outside director ratio on institutional ownership presence. This variable is proxy of more control and independence of board members reducing agency costs among large shareholders. The largest sensitivity is within independent investors (Col.6). The marginal effect is 0.26 , which implies a change in $6.7 \%$ on the probability of having an investment firm, mutual, and trust fund due to a 
change in 1 standard deviation change [0.27] in outside director ratio. This result is consistent with the agency view and monitoring of institutional blockholders.

Second, institutional investors value more directors with a master’s degree, and dislike members whose bachelors are not either in business or law. Director's education as proxy of human capital enhances investor monitoring, fostering firm disclosure standards (Bird and Karolyi, 2016). Third, Grey investors value positively background such as previous experience as CEO (Col. 4), while independent investors prefer directors that are or were entrepreneurs as founders of commercial firms (Col. 6). This finding is consistent with the resource base view of director diversity. All above regression coefficients are significant at 5\% level.

[TABLE 5 HERE]

\subsection{Institutional investors control rights (shares)}

This section presents the results of institutional blockholder ownership holdings (shares) based on baseline model Eq.1. These regressions control for firm effects, keeping all time-invariant variables in the model. ${ }^{12}$ Baseline regressions also include industry, country and year fixed effects. Table 6 summarizes the main results regarding the determinants of firm institutional shareholdings by investor heterogeneity. The results in general confirm the direction regarding the preferences of institutional investors according to their monitoring role type-i.e., grey versus independent investors- . Four additional comments deserve further explanation. First, institutional investors have asymmetric preferences regarding gender diversification within boards. Grey investor ownership exhibit a positive marginal effect $\left(\beta_{4}=0.028\right)$ while for

\footnotetext{
12 The Lagrange test rejects the pooled model in favor of a panel data specification. The Hausman specification test does not reject the null hypothesis of the RE specification is the true model.
} 
independent that effect is negative $\left(\beta_{4}=-0.128\right)$. For the total sample overall marginal effect is negative $\left(\beta_{4}=-0.112\right)$.

This finding suggest that gender is a mechanism to enhance director's monitoring role for grey investors, as it was the justification for establishing female quotas in Norway in 2003 and followed by other European countries such as Finland (2004) and Italy (2011). Nonetheless, gender has a negative association for independent investors, in line with the results for that mandatory policy that show a negative effect of the implementation of mandatory quota policy on firm market value (Ahern and Dittmar, 2012; Matsa and Miller, 2013) or female director appointments are explained by family connections (Bianco, 2015). Both arguments agree that there is no presumption that these new directors will be as qualified as the incumbent ones.

Second, grey investors like foreign directors $\left(\beta_{5}=0.019\right)$ while independent investors are indifferent ${ }^{13}$. Diverse boards characterized by appointing foreign directors reduce the risk of group thinking. This finding is consistent with the agency view that highlights director's ability in exerting effective monitoring that foster positive changes on firm corporate governance.

Third, independent institutional investors can be explained by director specific entrepreneurial experience $\left(\beta_{9}=0.137\right)$ but dislike directors with experience within the public sector. Grey investor do not show any relationship with director's profiles. This result suggest that grey investors are more concerned for corporate governance standards and directors' capability of exerting direct monitoring. Independent directors are more concern on director relational capital to overhaul firm business opportunities. These coefficients are significant at $5 \%$ level.

Fourth, a random effects regression (RE) was performed to control for time invariant firmspecific ownership variables. Three ownership variables are used to explore institutional

\footnotetext{
${ }^{13}$ That is, the regression coefficient is not statistically significant.
} 
ownership: the cash flow to voting rights wedge for the largest shareholder, blockholder ownership concentration and second shareholder equity rights. Ownership records in our study shows that institutional investors are blockholders within the top 3 shareholders in $57 \%$ of the firm year observations, institutional investors are the largest blockholder in $30 \%$ of the cases, on average the first and second blockholder holds $48 \%$ and $13 \%$ of equity rights respectively, and Herfindal index for the top four shareholders is $33 \%$. In $49 \%$ of the sample the largest shareholder has more than $50 \%$ of firm equity (Table A2). Thus, in the sample, corporate ownership follows a multiple blockholder structure, from which we expect active blockholder contestability and investor activism by institutional investor, as external governance mechanisms.

The RE regressions show on one side that independent investors increase their shareholdings (Col. 3) either with excess of control rights (wedge) of the largest blockholder $\left(\beta_{11}=0.045\right)$ or the ownership concentration index increases $\left(B_{12}=0.192\right)$. This implies for instance that a 1 standard deviation change in the wedge between ownership and control [0.33] will raise independent investor ownership by 150 base points. Similarly, a 1 standard deviation change in the Herfindal index [0.25] increases independent investor holdings by 480 base points. For grey investors these marginal effects are not significant.

On the other side the average institutional investor shareholding, regardless their type, increases with the amount of equity held by the second blockholder being or not an institutional investor (Col.1). For the total sample the marginal effect is positive $\left(B_{13}=0.296\right)$. Institutional ownership raises 307 base points due to a 1 standard deviation change in the second blockholder equity. The above regression coefficients are statistically significant at 5 $\%$ level. 
There are two arguments that explain these results. First, institutional investors as blockholders perceive that higher cash flow rights in hands of the controller owner reduces agency costs derived from rent diversion. Empirical studies that measure separation between firm ownership and control show that cash flow to voting rights ratio tend to 1 in two extreme ownership structures: widely held and absolute direct control - i.e., largest shareholder with more than 50\% of equity - (Gutiérrez and Pombo, 2009). Second, Empirical results from regional or country case studies on the marginal effects of blockholder identity and firm value confirm that the kind of second blockholder is vitally important when it comes to contesting the agency costs of controlling owners. The findings support a value premium across listed firms in East Asia (Atig et al., 2008), Spain (Sacristan et al., 2015) or Latin America (Pombo and Taborda, 2017).

The positive marginal effect found between the wedge variable and independent investor ownership ( $\left.\beta_{11}=0.045\right)$ at first glance is opposite to the expected one (Col.3). Deviations from one share one vote rule is one of the sources for cash flow tunneling, self-dealing and related transactions. However, it reinforces our findings that independent investors are less concern on firm specific governance practices and they are more focus on the benefits of business opportunities and board members relational capital bring to firms they have portfolio positions.

\section{[TABLE 6 HERE]}

\subsection{Robustness analysis}

This section reports a robustness analysis to back up the results reported above and rule out potential endogeneity issues. Two approaches are undertaken: i) instrumental variables regression and ii) institutional ownership and board structure dynamics. 


\subsubsection{Instrumental variables}

Instrumental variables asks whether the results hold to misspecifications tests due to potential endogeneity effect embedded in the estimation results. Empirical literature on corporate finance stresses the potential endogeneity between firm value and ownership structure (Renders and Gaeremynck, 2006; Bascle, 2008; Larcker and Rusticus, 2010; Roberts and Whited, 2013). The main endogeneity issue in the econometric estimation in this case, regards the dual causality between firm return on assets (ROA) and institutional ownership. In that sense, institutional investors design long term portfolios on high valued firms but, at the same time blockholder intervention and monitoring improves firm governance mechanisms, performance and corporate value. In this same line, a firm's poor performance may lead investors to sale their shares and 'vote with their feet' (Parrino, et al, , 2003). Therefore, simultaneity is the most likely endogeneity issue in the econometric model.

To address these issues, we relied on the IV estimations on the context of GMM under unknown heteroscedasticity (Baum, et al., 2007). The estimates are based on the validity of two main instruments: i) Leverage, calculated as the ratio of total liabilities to total assets. Leverage is a variable significantly and negatively correlated with firm performance as found in Elyasiani and Jia (2010), Anderson and Reeb (2003), and Lin and Fu (2017); ii) Growth opportunities defined as the percentage of sales growth compared to the previous year. A company with higher sales growth is expected to have a higher valuation.

Table 7 displays the main results. Col.1 displays the baseline RE model without instruments. The next regression equations from Col.2 to Col. 5 show the IV estimates under RE and GMM specifications. Three main comments arise from that table. To begin with, there is no statistical evidence of endogeneity. Therefore, the set of tests used to validate the IV analysis favor the 
original estimation and suggest that the IV estimation results should not be taken as definitive. Pvalues are in all cases greater than $40 \%$, for the identified and over identified systems (Col. 3 to 5) far above the critical values for rejecting the null hypothesis.

From this finding the remaining tests comply with the standard procedure when estimating IV regressions. The weak instruments test is rejected (high values of the statistic). Therefore, the set of instruments become a valid set of variables to uncover an endogenous process within the estimation. The under-identification test is also rejected, with zero probability on the null hypothesis of under-identification. The Hansen-J test does not reject the null hypothesis of instrument exogeneity for the over identified models (Col.4 and 5). Their p-values are 0.71 and 0.15 respectively. Rejecting the Hansen $J$-test indicates that at least one instrument is not valid.

Regarding the moderating variables in the model, the main interest of the IV estimates is on the board of directors' variables - whether they change or not after acknowledging potential endogeneity- and the statistical test checking the validity of the IV regression. On that regard the board structure variables keep the sign, size and significance on those regressors that are statistically significant under the RE specification reported in the findings section. In the pooled IV estimates the dummy variable for CEO-COB duality becomes non-significant but it keeps the effect size. On regards of director characteristics, The IV estimates show consistently and statistically significant that female directors, directors with undergrad studies different to business and law, directors with high public profile have a negative effect on institutional investor holdings consistent with the preferences of independent investors discussed in the previous section. The remaining variables keep the size and sign regardless their significance.

We replicate the IV estimates according to investor heterogeneity for the RE and IV-GMM under unknown heteroscedasticity. Results show that the direction of direction size, and 
significance regarding the preferences on board structure and director characteristics of institutional investors hold for all cases. For instance, grey investors like female and foreign directors, while independent investors prefer directors with entrepreneurial experience. Table A.3 in the appendix display these results.

\section{[TABLE 7 HERE]}

\subsubsection{Intuitional ownership and board dynamics}

The second robustness exercise performs linear regressions exploring whether the dynamics of institutional ownership can be explained by the dynamics of board composition, keeping the explanatory variables initially used in the baseline results. The logic of this check is: if changes along time in board composition are linked to institutional ownership changes, the nature of the econometric results previously discussed would be questionable on the grounds that institutional investors entered strategically after changes in ownership occurred. The estimated equation for the first and second shareholder is:

\section{$\Delta$ Institutional Ownership $=f(\triangle B O D$ characteristics $)$}

The dynamics of institutional ownership explained by the dynamics of board of director's characteristics (lagged and forwarded) is also used to examine whether changes in the board of directors lagged and ahead can explain the entry or exit of institutional investors. If this is the case a reverse causality mechanism would be observed, questioning the validity of the baseline results as well. The estimated equations are:

$$
\Delta \text { Institutional Ownership }=f(\triangle B O D \text { characteristics }(\text { Lag, Forward }))
$$

This series of regressions are a simplified empirical check of whether changes in the board composition have determined the entry of institutional ownership. This endogeneity test intends to understand if the relationship found and discussed in the baseline results are robust to the variable's 
dynamics. If there where such dynamic effect the panel data evidence discussed previously would be questionable.

The regression results of the dynamics of institutional investors and board composition dynamics is presented in Table 8. The coefficients showing the change in board characteristics, lagged or forward with respect to the change in time in presence of institutional investors, the first shareholder and the second are all statistically zero. The joint statistical significance test (F-Test) also suggests all coefficients can be cero. A few coefficients are individually significant, however these do not contradict previous results or the logic discussed in the results section. Therefore the estimation results are deemed as not informative and against a source of endogeneity that could invalidate the baseline results.

\section{[TABLE 8 HERE]}

\section{Conclusions}

This paper showed the relationship between board composition and institutional investors in Latin America by providing new evidence regarding the association and causality that director heterogeneity and board structures have on the presence of institutional investors as large shareholders and their holdings. Board diversity elements constitute a key factor in the decision whether to invest on stock securities by institutional investors across the region.

The econometric results, on the one hand, suggest grey institutional investors prefer experience, education and diversity in the board of directors, while dislike entrenchment and CEO related factors. On the other hand, independent investors dislike diversity, while prefer board experience related factors. Looking at the specific variables, grey investors invest more in firms with foreigners and highly educated board members; while independent investors are indifferent when boards have outsiders and foreign directors. The invest less in firms with 
boards members with experience in public sector, however will increase investment when there is an experienced CEO and founders. High qualified directors and boards constitute a positive signal of firms' internal corporate governance practices, especially for grey investors (pension funds) that tend to have longer investment horizons and business relations that independent investment firms who manage shorter investment turnovers. Hence, board diversity becomes a key element to enhance investor protection in countries ranked with low CG levels such as the one study from Latin America.

\section{References}

Adams, R. and D. Ferreira (2003) Diversity and incentives: evidence from corporate boards. Working papers, University of Stockholm

Adams, R. and D. Ferreira (2009). Women in the boardroom and their impact on governance and performance. Journal of financial economics 94(2), 291-309.

Adams, R. B. and D. Ferreira (2007). A theory of friendly boards. The Journal of Finance 62(1), 217-250.

Aggarwal, R., I. Erel, R. Stulz, and R. Williamson (2010). Differences in governance prac- tices between us and foreign firms: Measurement, causes, and consequences. Review of Financial Studies 23(3), 3131-3169.

Aggarwal, R., L. Klapper, and P. D. Wysocki (2005). Portfolio preferences of foreign institutional investors. Journal of Banking \& Finance 29(12), 2919-2946.

Aggarwal, R., Erel, I., Ferreira, M., Matos, P., 2011. Does governance travel around the world? Evidence from institutional investors. Journal of Financial Economics 100, 154-181

Almazan, A. and J. Suarez (2003). Entrenchment and severance pay in optimal gover- nance structures. The Journal of Finance 58(2), 519-548.

Anderson, R. C. and J. M. Bizjak (2003). An empirical examination of the role of the ceo and the compensation committee in structuring executive pay. Journal of Banking \& Finance 27(7), 1323-1348.

Bebchuk, Lucian, Alon Brav, and Wei Jiang, 2015, The long-term effects of hedge fund activism, Columbia Law Review 115, 1085-1156.

Blume, D. and F. Alonso (2007). Institutional investors and corporate governance in latin america. Financial Market Trends 2007(2), 93-131.

Braun M., Raddatz C., (2010) Banking on Politics: When Former High-ranking Politicians Become Bank Directors, World Bank Economic Review 24,: 234-279.

Brav, A., W. Jiang, F. Partnoy, and R. Thomas (2008). Hedge fund activism, corporate governance, and firm performance. The Journal of Finance 63(4), 1729-1775.

Brian J. Bushee, C. F. N. (2000). Corporate disclosure practices, institutional investors, and stock return volatility. Journal of accounting research 38, 171-202.

Brown, L. D. and M. L. Caylor (2006). Corporate governance and firm valuation. Journal

of accounting and public policy 25(4), 409-434.

Bushee, B. J., M. E. Carter, and J. Gerakos (2013). Institutional investor preferences for corporate governance mechanisms. Journal of Management Accounting Research 26(2), 123-149.

Campello, M., Lin, C., Ma, Y., Zou, H., (2011), "The Real and Financial Implications of Corporate Hedging," Journal of Finance, 66, 1615-1647.

Carleton, W. T., J. M. Nelson, and M. S. Weisbach (1998). The influence of institutions on corporate governance through private negotiations: Evidence from tiaa-cref. The Journal of Finance 53(4), 1335-1362.

Carter, D. A., B. J. Simkins, and W. G. Simpson (2003). Corporate governance, board diversity, and firm value. Financial review 38(1), 33-53. 
Chung, K. H. and H. Zhang (2011). Corporate governance and institutional ownership. Journal of Financial and Quantitative Analysis 46(01), 247-273.

Dahya, J., O. Dimitrov, and J. J. McConnell (2008). Dominant shareholders, corporate boards, and corporate value: A cross-country analysis. Journal of Financial Economics 87(1), 73-100.

De-La-Hoz, M.-C. and C. Pombo (2016). Institutional investor heterogeneity and firm valuation: Evidence from Latin America. Emerging Markets Review 26, 197-221.

Del Guercio, D. and J. Hawkins (1999). The motivation and impact of pension fund activism. Journal of financial economics 52(3), 293-340.

Dionne G, Maalaoui O, Triki T., (2013), Risk management and corporate governance: The importance of independence and financial knowledge, SSRN, http://dx.doi.org/10.2139/ssrn.2020987

Edmans, A. (2009). Blockholder trading, market efficiency, and managerial myopia. Journal of Finance 64(6), 2481-2513.

Edmans, A., 2014. Blockholders and Corporate Governance. Annual Review of Financial Economics 6, 23-50

Edmans, A., \& Manso, G. (2011). Governance through trading and intervention: A theory of multiple blockholders. Review of Financial Studies, 24(7), 2395-2428.

Farrell, K. A. and P. L. Hersch (2005). Additions to corporate boards: the effect of gender. Journal of Corporate finance 11(1), 85-106.

Ferreira, M. A. and P. Matos (2008). The colors of investors' money: The role of institu- tional investors around the world. Journal of Financial Economics 88(3), 499-533.

Gaspar, J., M. Massa, and P. Matos (2005). Shareholder investment horizons and the market for corporate control. Journal of financial economics 76(1), 135-165.

Gertler, M. and R. G. Hubbard (1993). Corporate financial policy, taxation, and macroeconomic risk. The Rand Journal of Economics, 286-303.

Gompers, P., J. Ishii, and A. Metrick (2003). Corporate governance and equity prices. Quarterly Journal of Economics 118(1), 107-156.

Gompers, P. A. and A. Metrick (2001). Institutional investors and equity prices. The Quarterly Journal of Economics 116(1), 229-259.

Hillman, A. J., Cannella, A. A., \& Paetzold, R. L. (2000). The resource dependence role of corporate directors: Strategic adaptation of board composition in response to environmental change. Journal of Management studies, 37(2), 235-256.

Hillman, A. J., \& Dalziel, T. (2003). Boards of directors and firm performance: Integrating agency and resource dependence perspectives. Academy of Management Review, 28(3), 383-396.

Hillman, A. J. (2015). Board diversity: Beginning to unpeel the onion. Corporate Governance: An International Review, 23(2), 104-107.

Hirschman, A. O. (1970). Exit, voice, and loyalty: Responses to decline in firms, organizations, and states. Cambridge, MA: Harvard Univ. Press.

Holmstrom, B. and J. Tirole (1993). Market liquidity and performance monitoring. Journal of Political Economy, 678-709.

Jensen, M. C. (1993). The modern industrial revolution, exit, and the failure of internal control systems. The Journal of Finance 48(3), 831-880.

Leuz, C., K. V. Lins, and F. E. Warnock (2010). Do foreigners invest less in poorly governed firms? Review of Financial Studies 23(3), 3245-3285.

Li, D., F. Moshirian, P. K. Pham, and J. Zein (2006). When financial institutions are large shareholders: the role of macro corporate governance environments. The Journal of Finance 61(6), 2975-3007.

McCahery, J. A., Z. Sautner, and L. T. Starks (2016) Behind the scenes: The corporate governance preferences of institutional investors. The Journal of Finance, 71 (6): 2905-2932

Navissi, F. and V. Naiker (2006). Institutional ownership and corporate value. Managerial Finance 32(3), 247256.

O’Connell, P. G. J. and M. Teo (2009). Institutional investors, past performance, and dynamic loss aversion. Journal of Financial and Quantitative Analysis 44(1), 155-188.

Pearce, J. A. and S. A. Zahra (1992). Board composition from a strategic contingency perspective, Journal of Management Studies 29(4), 411-438

Perrault, E. (2015). Why does board gender diversity matter and how do we get there? the role of shareholder activism in deinstitutionalizing old boys' networks. Journal of Business Ethics 128(1), 149-165.

Shleifer, A. and R. W. Vishny (1997). A survey of corporate governance. The journal of finance 52(2), 737783. 
Singh, V. and S. Vinnicombe (2004). Why so few women directors in top uk board rooms? evidence and theoretical explanations. Corporate Governance: An International Review 12(4), 479-488.

Szantho,B., (2012). One and two-tier corporate governance systems.

Web site, http://www.internationallawoffice.com. Accessed: January, 2015.

Terjesen, S., R. Sealy, and V. Singh (2009). Women directors on corporate boards: A review and research agenda. Corporate governance: an international review 17(3), 320-337.

Terjesen, S. and V. Singh (2008). Female presence on corporate boards: A multi-country study of environmental context. Journal of Business Ethics 83(1), 55-63.

Wahal, S. (1996). Pension fund activism and firm performance. The Journal of Financial and Quantitative Analysis 31(1), 1-23.

Walsh, J. P. and J. K. Seward (1990). On the efficiency of internal and external corporate control mechanisms. Academy of management review 15(3), 421-458.

Wang, Y., P. Jin, and C. Yang (2016). Relations between the professional backgrounds of independent directors in state-owned enterprises and corporate performance. International Review of Economics \& Finance 42, 404411.

Woidtke, T. (2002). Agents watching agents?: evidence from pension fund ownership and firm value. Journal of Financial Economics 63(1), 99-131. 
FIGURES

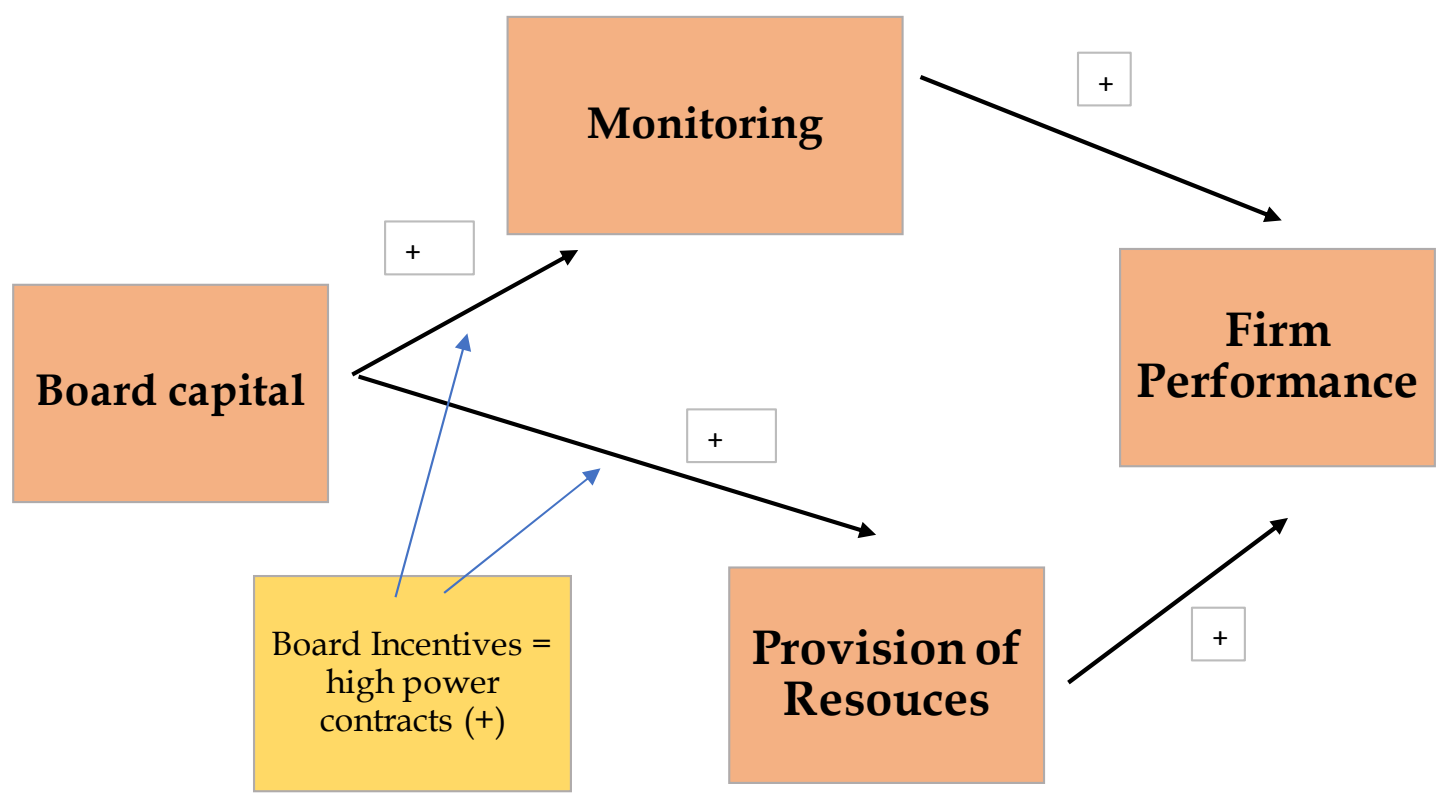

Fig.1 Board capital, agency and resource based views

Source: Adapted from Hillman and Datziel (2003) 


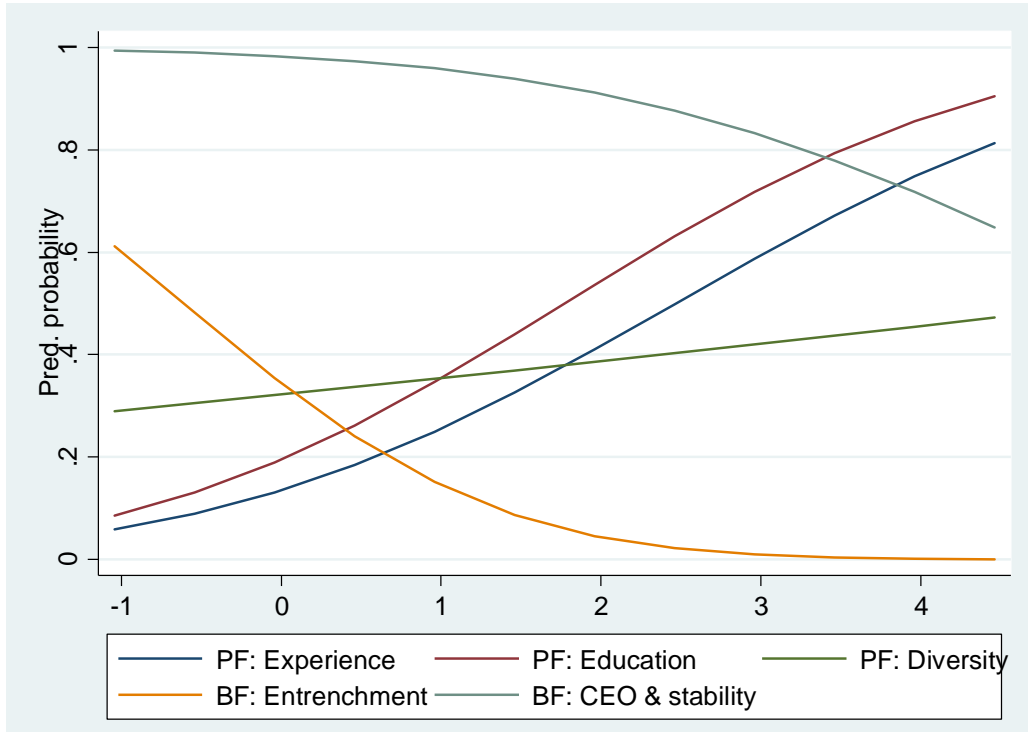

Grey Investors

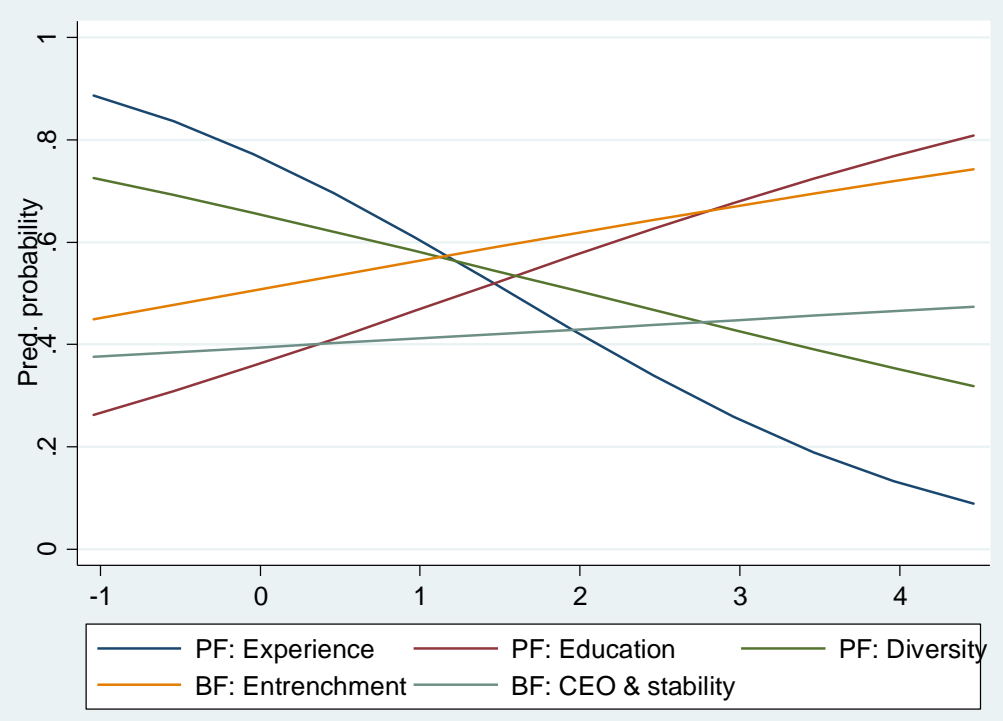

Independent Investors

Fig.2 Probit Model - Predicted probabilities by investor color using factors scores as explanatory variables. 
Table 1 - Sample construction. Number of firms in the sample

Total number of firms (Averages 2003-2011)

Average reported Datastream mnemonics

4809

Removing non-active firms

1552

Removing firms with non-equity instruments

1154

Removing banks and financial firms

Removing firms with insufficient ownership

information

604

Removing firms with insufficient board of director's

information

Total Sample

Source: Own estimates based on Thomson-one. 
Table 2

Descriptive statistics - Board of directors and institutional ownership variables

Panel A - Board structure variables

\begin{tabular}{lrrrrr}
\hline Variable & Obs & Mean & Std. & Min & Max \\
Board Size & 4,697 & 9.963 & 5.020 & 2 & 35 \\
Board turnover annual & 4,706 & 0.714 & 1.369 & 0 & 19 \\
Board turnover ratio & 4,697 & 0.067 & 0.125 & 0 & 1 \\
Insider-Employee ratio & 4,697 & 0.210 & 0.254 & 0 & 1 \\
Outsider director ratio & 4,697 & 0.770 & 0.267 & 0 & 1 \\
Independent director ratio & 4,697 & 0.121 & 0.179 & 0 & 1 \\
Female director ratio & 4,697 & 0.067 & 0.123 & 0 & 1 \\
Foreign director ratio & 4,697 & 0.244 & 0.250 & 0 & 1 \\
CEO-COB Dummy & 4,706 & 0.171 & 0.377 & 0 & 1 \\
Former firm CEO ratio & 4,697 & 0.109 & 0.140 & 0 & 1
\end{tabular}

\section{Panel B Director Characteristics variables}

\begin{tabular}{lrrrrr}
\hline Director Age & 2,516 & 52.14 & 8.27 & 25 & 82.5 \\
Founder experience ratio & 4,408 & 0.042 & 0.089 & 0 & 0.58 \\
Public sector experience ratio & 4,418 & 0.037 & 0.085 & 0 & 0.67 \\
Business undergrad ratio & 4,697 & 0.281 & 0.220 & 0 & 1 \\
Law undergrad ratio & 4,697 & 0.093 & 0.128 & 0 & 0.75 \\
Masters studies ratio & 4,697 & 0.232 & 0.280 & 0 & 1 \\
CEO experience ratio & 4,420 & 0.313 & 0.256 & 0 & 1
\end{tabular}

Panel C Institutional Ownership variables - Presence and shares

\begin{tabular}{llllll}
\hline Institutional Investor (Dummy) among first 3 LSH & 4702 & 0.573 & 0.495 & 0 & 1 \\
Grey Ins. investor (Dummy) & 4706 & 0.108 & 0.310 & 0 & 1 \\
Indep. Inst. investor (Dummy) & 4706 & 0.541 & 0.498 & 0 & 1 \\
Foreign inst. Investor (Dummy) & 4706 & 0.122 & 0.328 & 0 & 1 \\
1st BHL is Institutional Investor (Dummy) & 4426 & 0.309 & 0.462 & 0 & 1 \\
2nd BHL is Institutional Investor (Dummy) & 3876 & 0.429 & 0.495 & 0 & 1 \\
Institutional investor (Shares) among first 3 LSH & 3284 & 0.217 & 0.263 & 0 & 1 \\
Institutional investor (Shares) grey & 4498 & 0.017 & 0.077 & 0 & 1 \\
Institutional investor (Shares) independent & 4498 & 0.187 & 0.264 & 0 & 1 \\
Institutional investor (Shares) foreign & 4283 & 0.045 & 0.162 & 0 & 1 \\
\hline
\end{tabular}

Sources: Thomson one, Tomson's World Scope, Economatica, companies’ annual reports (Internet based) and web-pages, regulatory bodies, other internet sources (i.e., directors' CVs and Linkedin). Authors’ own calculations.

Notes: BHL stands for blockholder. 
Table 3 - Variables classification and loadings for factor analysis

Panel A - Factor loads

Board as a whole

\begin{tabular}{lrr}
\hline & Factor 1 & Factor 2 \\
\cline { 2 - 3 } Outsiders & -0.906 & -0.097 \\
Turnover & 0.278 & -0.611 \\
Employee & 0.912 & 0.160 \\
CEO on board & 0.468 & 0.673 \\
CEO COB & 0.263 & 0.747 \\
\hline
\end{tabular}

Board members' characteristics

\begin{tabular}{lrrrr}
\hline & Factor 1 & & Factor 2 & Factor 3 \\
\cline { 2 - 2 } Female & 0.161 & & -0.158 & \\
Foreigners & -0.126 & & 0.179 & 0.729 \\
Edu. Masters & 0.813 & & -0.046 & -0.119 \\
Edu. Non-business or law & 0.688 & 0.179 & 0.282 \\
Experience CEO & 0.181 & 0.778 & 0.006 \\
Experience Founder & -0.102 & 0.725 & 0.115 \\
Experience Public sector & 0.510 & 0.436 & -0.291 \\
\hline
\end{tabular}

Panel B - Board factor score indices: summary of statistics

\begin{tabular}{lccccc}
\hline Score Index & Obs & Mean & Std Dev & Min & Max \\
People factor experience & 4,403 & 0 & 1 & -2.44 & 4.30 \\
People factor eductation & 4,403 & 0 & 1 & -2.33 & 4.84 \\
People factor Diversity & 4,403 & 0 & 1 & -2.79 & 5.27 \\
Board factor entrechement & 4,697 & 0 & 1 & -1.04 & 4.84 \\
Board factor CEO \& stability & 4,697 & 0 & 1 & -7.36 & 6.01 \\
\hline
\end{tabular}

Notes: The name of each factor loads is:

Board factor 1 = Board factor entrenchment; Board factor 2 = Board factor CEO and Stability

Director factor 1 = people factor education; Director factor 2 = people factor experience; Director factor 3 = people factor diversity

The variables used in factor analysis measured as ratio with respect to board size except those with an asterisk. The set of director characteristics variables are i) women directors, ii) foreigner directors, iii) director with master's degree, iv) director have undergraduate studies different from law or business, v) director with experience as CEO, vi) director with experience as founder of another firm, vii) director with experience in public sector.

The set of board structure variables are i) outside directors, ii) director annual turnover*, iii) number of executive directors*, iv) CEO director and v) CEO-COB director 
Table 4 - Presence Institutional Ownership (factor variables)

(Probit Regressions - firm, industry and country fixed effects)

Dependent variable: institutional blockholder ownership dummy

\begin{tabular}{|c|c|c|c|c|c|c|c|}
\hline Variables & & $\begin{array}{c}\text { Total } \\
\text { II } \\
\text { Col.1 } \\
\end{array}$ & $\begin{array}{c}\text { Mg. } \\
\text { Effects } \\
\text { Col.2 } \\
\end{array}$ & $\begin{array}{c}\text { Grey } \\
\text { II } \\
\text { Col.3 }\end{array}$ & $\begin{array}{c}\text { Mg. } \\
\text { Effects } \\
\text { Col.4 }\end{array}$ & $\begin{array}{c}\begin{array}{c}\text { Indep } \\
\text { II }\end{array} \\
\text { Col.5 } \\
\end{array}$ & $\begin{array}{c}\text { Mg. } \\
\text { Effects } \\
\text { Col.6 } \\
\end{array}$ \\
\hline \multicolumn{8}{|l|}{ Factor } \\
\hline People Factor: Experience (Rotated) & B1 & $\begin{array}{r}-0.401 * * * \\
(0.141)\end{array}$ & $\begin{array}{r}-0.116^{* * *} \\
(0.0404)\end{array}$ & $\begin{array}{r}0.448^{* *} \\
(0.221)\end{array}$ & $\begin{array}{c}0.129 * * \\
(0.0632)\end{array}$ & $\begin{array}{r}-0.465^{* * *} \\
(0.145)\end{array}$ & $\begin{array}{r}-0.140 * * * \\
(0.0432)\end{array}$ \\
\hline People Factor: Education (Rotated) & B2 & $\begin{array}{c}0.192 * \\
(0.109)\end{array}$ & $\begin{array}{c}0.0556^{*} \\
(0.0315)\end{array}$ & $\begin{array}{r}0.487^{* *} \\
(0.206)\end{array}$ & $\begin{array}{c}0.140 * * \\
(0.0587)\end{array}$ & $\begin{array}{r}0.274^{* *} \\
(0.117)\end{array}$ & $\begin{array}{r}0.0827^{* *} \\
(0.0349)\end{array}$ \\
\hline People Factor: Diversity (Rotated) & B3 & $\begin{array}{r}-0.0284 \\
(0.117)\end{array}$ & $\begin{array}{r}-0.00821 \\
(0.0338)\end{array}$ & $\begin{array}{l}0.0880 \\
(0.196)\end{array}$ & $\begin{array}{r}0.0254 \\
(0.0565)\end{array}$ & $\begin{array}{r}-0.195 \\
(0.131)\end{array}$ & $\begin{array}{r}-0.0588 \\
(0.0393)\end{array}$ \\
\hline Board Factor: Entrenchment (Rotated) & B4 & $\begin{array}{r}0.165 \\
(0.121)\end{array}$ & $\begin{array}{r}0.0477 \\
(0.0351)\end{array}$ & $\begin{array}{r}-0.659 * * * \\
(0.243)\end{array}$ & $\begin{array}{r}-0.190 * * * \\
(0.0691)\end{array}$ & $\begin{array}{r}0.141 \\
(0.125)\end{array}$ & $\begin{array}{r}0.0426 \\
(0.0377)\end{array}$ \\
\hline Board Factor: CEO \& stability & B5 & $\begin{array}{r}0.102 \\
(0.0728) \\
\end{array}$ & $\begin{array}{r}0.0296 \\
(0.0210) \\
\end{array}$ & $\begin{array}{r}-0.390 * * * \\
(0.143) \\
\end{array}$ & $\begin{array}{r}-0.112^{* * *} \\
(0.0405) \\
\end{array}$ & $\begin{array}{r}0.0456 \\
(0.0742) \\
\end{array}$ & $\begin{array}{r}0.0138 \\
(0.0224) \\
\end{array}$ \\
\hline \multicolumn{8}{|l|}{ Ownership } \\
\hline Wedge & B6 & $\begin{array}{l}0.385^{*} \\
(0.219) \\
\end{array}$ & $\begin{array}{r}0.111^{*} \\
(0.0630) \\
\end{array}$ & $\begin{array}{r}-0.0520 \\
(0.374) \\
\end{array}$ & $\begin{array}{r}-0.0150 \\
(0.108) \\
\end{array}$ & $\begin{array}{l}0.0971 \\
(0.233) \\
\end{array}$ & $\begin{array}{r}0.0293 \\
(0.0701) \\
\end{array}$ \\
\hline \multicolumn{8}{|l|}{ Financial } \\
\hline Return On Assets (ROA) & B7 & $\begin{array}{r}0.417 \\
(0.467)\end{array}$ & $\begin{array}{r}0.121 \\
(0.135)\end{array}$ & $\begin{array}{c}-0.671 \\
(0.719)\end{array}$ & $\begin{array}{r}-0.193 \\
(0.207)\end{array}$ & $\begin{array}{r}-0.116 \\
(0.537)\end{array}$ & $\begin{array}{r}-0.0351 \\
(0.162)\end{array}$ \\
\hline Leverage & B8 & $\begin{array}{r}-0.747 * * \\
(0.373)\end{array}$ & $\begin{array}{r}-0.216^{* *} \\
(0.108)\end{array}$ & $\begin{array}{r}0.544 \\
(0.584)\end{array}$ & $\begin{array}{r}0.157 \\
(0.168)\end{array}$ & $\begin{array}{r}-1.524^{* * *} \\
(0.448)\end{array}$ & $\begin{array}{r}-0.459 * * * \\
(0.134)\end{array}$ \\
\hline Firm Size (Log. Assets) & B9 & $\begin{array}{l}-0.195^{* *} \\
(0.0933)\end{array}$ & $\begin{array}{r}-0.0565^{* *} \\
(0.0269)\end{array}$ & $\begin{array}{r}0.352^{* *} \\
(0.162)\end{array}$ & $\begin{array}{r}0.102^{* *} \\
(0.0462)\end{array}$ & $\begin{array}{l}-0.118 \\
(0.109)\end{array}$ & $\begin{array}{r}-0.0354 \\
(0.0327)\end{array}$ \\
\hline Firm Beta & B10 & $\begin{array}{l}0.0819 \\
(0.148)\end{array}$ & $\begin{array}{r}0.0237 \\
(0.0428)\end{array}$ & $\begin{array}{r}-0.0785 \\
(0.198)\end{array}$ & $\begin{array}{c}-0.0226 \\
(0.0570)\end{array}$ & $\begin{array}{c}-0.117 \\
(0.148)\end{array}$ & $\begin{array}{r}-0.0352 \\
(0.0445)\end{array}$ \\
\hline Tangibility (PPE/Assets) & B11 & $\begin{array}{l}0.677^{*} \\
(0.401)\end{array}$ & $\begin{array}{c}0.196^{*} \\
(0.116)\end{array}$ & $\begin{array}{r}-0.559 \\
(0.744)\end{array}$ & $\begin{array}{r}-0.161 \\
(0.214)\end{array}$ & $\begin{array}{l}0.0121 \\
(0.454)\end{array}$ & $\begin{array}{r}0.00365 \\
(0.137)\end{array}$ \\
\hline Stock Turnover p75 & B12 & $\begin{array}{l}0.0523 \\
(0.123) \\
\end{array}$ & $\begin{array}{r}0.0151 \\
(0.0356) \\
\end{array}$ & $\begin{array}{r}-0.0615 \\
(0.184) \\
\end{array}$ & $\begin{array}{r}-0.0177 \\
(0.0531) \\
\end{array}$ & $\begin{array}{r}0.113 \\
(0.131) \\
\end{array}$ & $\begin{array}{r}0.0341 \\
(0.0395) \\
\end{array}$ \\
\hline \multicolumn{8}{|l|}{ MACRO } \\
\hline Emerging Markets Bond Index (EMBI) & B13 & $\begin{array}{r}-1.39 \mathrm{E}-05 \\
(7.59 \mathrm{e}-05)\end{array}$ & $\begin{array}{r}-4.03 \mathrm{E}-06 \\
(2.19 \mathrm{e}-05)\end{array}$ & $\begin{array}{c}-1.30 \mathrm{E}-04 \\
0.000119)\end{array}$ & $\begin{array}{c}-3.76 \mathrm{E}-05 \\
(3.43 \mathrm{e}-05)\end{array}$ & $\begin{array}{c}-1.22 \mathrm{E}-04 \\
(9.12 \mathrm{e}-05)\end{array}$ & $\begin{array}{r}-3.68 \mathrm{E}-05 \\
(2.74 \mathrm{e}-05)\end{array}$ \\
\hline Market Capitalization (\% of GDP) & B14 & $\begin{array}{r}-2.35 \mathrm{E}-03 \\
(2.04 \mathrm{e}-03)\end{array}$ & $\begin{array}{r}-6.78 \mathrm{E}-04 \\
(5.90 \mathrm{e}-04)\end{array}$ & $\begin{array}{c}-1.66 \mathrm{E}-03 \\
(3.00 \mathrm{e}-03)\end{array}$ & $\begin{array}{c}-4.79 \mathrm{E}-04 \\
(8.63 \mathrm{e}-04)\end{array}$ & $\begin{array}{r}3.07 \mathrm{E}-04 \\
(2.24 \mathrm{e}-03)\end{array}$ & $\begin{array}{r}9.24 \mathrm{E}-05 \\
(6.76 \mathrm{e}-04)\end{array}$ \\
\hline Property Rights & B15 & $\begin{array}{r}-0.865 \\
(0.823)\end{array}$ & $\begin{array}{r}-0.250 \\
(0.238)\end{array}$ & $\begin{array}{r}-0.896 \\
(1.301)\end{array}$ & $\begin{array}{r}-0.258 \\
(0.375)\end{array}$ & $\begin{array}{r}-1.608^{*} \\
(0.891)\end{array}$ & $\begin{array}{c}-0.485^{*} \\
(0.268)\end{array}$ \\
\hline Constant & & $\begin{array}{r}0.979 \\
(0.960) \\
\end{array}$ & & $\begin{array}{r}-2.349 \\
(1.467) \\
\end{array}$ & & $\begin{array}{r}2.967^{* * *} \\
(0.914) \\
\end{array}$ & \\
\hline Observations & & 1,547 & 1,547 & 681 & 681 & 1,286 & 1,286 \\
\hline Firm dummy & & Yes & Yes & Yes & Yes & Yes & Yes \\
\hline Industry dummy & & Yes & Yes & Yes & Yes & Yes & Yes \\
\hline Country dummy & & Yes & Yes & Yes & Yes & Yes & Yes \\
\hline Pseudo - R2 & & 0.256 & & 0.244 & & 0.231 & \\
\hline
\end{tabular}

Standard errors in parentheses; ${ }^{* * *} \mathrm{p}<0.01,{ }^{* *} \mathrm{p}<0.05,{ }^{*} \mathrm{p}<0.1$

Notes: II = Institutional Investors; $\mathrm{Mg}$. = marginal 
Table 5 - Presence Institutional Ownership - (individual variables)

Probit Regressions - Firm, Industry and Country Fixed Effects

Dependent variable: institutional blockholder ownership dummy

\begin{tabular}{|c|c|c|c|c|c|c|c|}
\hline \multirow[t]{2}{*}{ Variables } & & $\begin{array}{c}\text { Total } \\
\text { II }\end{array}$ & $\begin{array}{c}\text { Mg. } \\
\text { Effects }\end{array}$ & $\begin{array}{c}\text { Grey } \\
\text { II }\end{array}$ & $\begin{array}{c}\text { Mg. } \\
\text { Effects }\end{array}$ & $\begin{array}{c}\text { Indep } \\
\text { II }\end{array}$ & $\begin{array}{c}\text { Mg. } \\
\text { Effects }\end{array}$ \\
\hline & & Col.1 & Col.2 & Col.3 & Col.4 & & \\
\hline \multicolumn{8}{|l|}{ Board Structure } \\
\hline \multirow[t]{2}{*}{ Outsiders in the board (ratio) } & B1 & $0.657^{* * *}$ & $0.233^{* * *}$ & $0.521^{* *}$ & $0.0945 * *$ & $0.739 * * *$ & $0.261^{* * *}$ \\
\hline & & $(0.149)$ & $(0.0524)$ & $(0.228)$ & $(0.0413)$ & $(0.149)$ & $(0.0528)$ \\
\hline \multirow[t]{2}{*}{ Board turnover annual } & B2 & -0.0226 & -0.00802 & 0.0101 & 0.00184 & $-0.0276^{*}$ & $-0.00959 *$ \\
\hline & & (0.0159) & $(0.00563)$ & $(0.0196)$ & $(0.00355)$ & $(0.0157)$ & $(0.00565)$ \\
\hline \multirow[t]{2}{*}{ CEO-COB (Dummy) } & B3 & 0.0444 & 0.0157 & $0.145^{*}$ & $0.0262 *$ & 0.0238 & 0.00658 \\
\hline & & $(0.0549)$ & $(0.0194)$ & $(0.0758)$ & $(0.0137)$ & $(0.0547)$ & $(0.0196)$ \\
\hline \multicolumn{8}{|l|}{ Board Diversity } \\
\hline \multirow[t]{2}{*}{ Female directors } & B4 & $-0.322^{*}$ & $-0.114^{*}$ & 0.212 & 0.0385 & -0.273 & -0.0938 \\
\hline & & $(0.179)$ & $(0.0634)$ & $(0.238)$ & $(0.0432)$ & $(0.176)$ & $(0.0632)$ \\
\hline \multirow[t]{2}{*}{ Foreign directors } & B5 & -0.153 & -0.0543 & 0.143 & 0.0260 & $-0.178 *$ & $-0.0643^{*}$ \\
\hline & & $(0.0959)$ & $(0.0339)$ & $(0.129)$ & $(0.0234)$ & $(0.0951)$ & $(0.0341)$ \\
\hline \multirow[t]{2}{*}{ Board members with MSc } & B6 & $0.722 * * *$ & $0.256 * * *$ & $1.071 * * *$ & $0.194^{* * *}$ & $0.519 * * *$ & $0.195^{* * *}$ \\
\hline & & $(0.138)$ & $(0.0482)$ & $(0.177)$ & $(0.0320)$ & $(0.136)$ & $(0.0484)$ \\
\hline \multirow[t]{2}{*}{ Undergraduate studies in non } & B7 & $-0.365 * * *$ & $-0.129 * * *$ & -0.292 & -0.0529 & $-0.295^{* *}$ & $-0.103^{* *}$ \\
\hline & & (0.139) & $(0.0492)$ & $(0.183)$ & $(0.0332)$ & $(0.138)$ & $(0.0494)$ \\
\hline \multirow[t]{2}{*}{ Director CEO experience } & B8 & 0.127 & 0.0450 & $0.444^{* * *}$ & $0.0805^{* * *}$ & 0.192 & 0.0726 \\
\hline & & $(0.124)$ & $(0.0440)$ & $(0.166)$ & $(0.0301)$ & $(0.124)$ & $(0.0442)$ \\
\hline \multirow[t]{2}{*}{ Director founder experience } & B9 & $0.443^{*}$ & $0.157^{*}$ & -0.413 & -0.0750 & $0.432 *$ & $0.153^{*}$ \\
\hline & & $(0.261)$ & $(0.0925)$ & $(0.408)$ & $(0.0739)$ & $(0.260)$ & $(0.0937)$ \\
\hline \multirow[t]{2}{*}{ Director public sector experience } & B10 & -0.344 & -0.122 & $-1.222 * * *$ & $-0.222 * * *$ & -0.369 & -0.126 \\
\hline & & $(0.316)$ & $(0.112)$ & $(0.415)$ & $(0.0752)$ & $(0.314)$ & $(0.111)$ \\
\hline \multicolumn{8}{|l|}{ Firm Financial } \\
\hline \multirow[t]{2}{*}{ Return On Assets (ROA) } & B11 & 0.145 & 0.0513 & 0.0703 & 0.0128 & -0.0681 & -0.0239 \\
\hline & & $(0.199)$ & $(0.0703)$ & $(0.255)$ & $(0.0462)$ & $(0.198)$ & $(0.0704)$ \\
\hline \multirow[t]{2}{*}{ Operating Income volatility } & B12 & $2.68 \mathrm{e}-05$ & $9.49 e-06$ & $2.54 \mathrm{e}-04 * *$ & $-4.60 \mathrm{e}-05^{* *}$ & $-1.21 e-05$ & -0.0599 \\
\hline & & $(7.76 e-05)$ & $(2.75 e-05)$ & $(1.14 \mathrm{e}-04)$ & $(2.07 e-05)$ & $(7.74 \mathrm{e}-05)$ & $(0.0411)$ \\
\hline \multirow[t]{2}{*}{ Firm Size ( Ln total assets) } & B13 & -0.00231 & -0.000818 & $0.0687 * * *$ & $0.0125^{* * *}$ & -0.00490 & -0.00253 \\
\hline & & $(0.0152)$ & $(0.00539)$ & $(0.0209)$ & $(0.00379)$ & $(0.0151)$ & $(0.00505)$ \\
\hline \multirow[t]{2}{*}{ Firm Beta } & B14 & -0.00427 & -0.00151 & -0.0692 & -0.0126 & -0.0602 & -0.0213 \\
\hline & & $(0.0520)$ & $(0.0184)$ & $(0.0768)$ & $(0.0139)$ & $(0.0510)$ & $(0.0183)$ \\
\hline \multirow[t]{2}{*}{ Tangibility ( PPE / assets) } & B15 & 0.142 & 0.0501 & $0.301 * *$ & $0.0546 * *$ & $-0.194^{*}$ & $-0.0675^{*}$ \\
\hline & & $(0.100)$ & $(0.0354)$ & $(0.133)$ & $(0.0241)$ & $(0.0998)$ & $(0.0355)$ \\
\hline Stock turnover p75. (Dummy) & B16 & $0.0955^{*}$ & $0.0338^{*}$ & $0.224^{* * *}$ & $0.0407 * * *$ & $0.112^{* *}$ & $0.0441 * *$ \\
\hline & & $(0.0532)$ & $(0.0188)$ & $(0.0649)$ & $(0.0118)$ & $(0.0527)$ & $(0.0188)$ \\
\hline Wedge ownership and control & B17 & $0.128 *$ & $0.0455^{*}$ & 0.129 & 0.0234 & -0.109 & -0.0392 \\
\hline & & $(0.0697)$ & $(0.0247)$ & $(0.0908)$ & $(0.0165)$ & $(0.0688)$ & $(0.0246)$ \\
\hline Country Macro & & & & & & & \\
\hline Emerging Markets Bond Index* & $\mathrm{B} 18$ & $-1.29 \mathrm{e}-05$ & $-4.57 e-06$ & $-3.51 e-05$ & $-6.37 e-06$ & $-3.54 \mathrm{e}-05$ & $-1.35 e-05$ \\
\hline & & $(4.59 e-05)$ & $(1.63 e-05)$ & $(5.21 \mathrm{e}-05)$ & $(9.44 \mathrm{e}-06)$ & $(4.63 e-05)$ & $(1.67 e-05)$ \\
\hline Market Capitalization (\% of GDP) & B19 & $-2.00 e-03 *$ & $-7.07 e-04 *$ & $-1.01 \mathrm{E}-03$ & $-1.84 \mathrm{E}-04$ & $-4.39 \mathrm{E}-04$ & $-1.39 \mathrm{E}-04$ \\
\hline & & $(1.17 e-03)$ & $(4.13 e-04)$ & $(1.47 e-03)$ & $(2.67 e-04)$ & $(1.15 e-03)$ & $(4.09-e-04)$ \\
\hline Property Rights & B20 & -0.354 & -0.125 & 0.360 & 0.0653 & -0.742 & -0.280 \\
\hline & & $(0.502)$ & $(0.178)$ & $(0.615)$ & $(0.112)$ & $(0.502)$ & $(0.176)$ \\
\hline Constant & & -0.146 & & $-1.661 * * *$ & & $0.566^{* *}$ & \\
\hline Observations & & 3,563 & 3,563 & 3,563 & 3,563 & 3,563 & 3,642 \\
\hline Firm dummy & & Yes & Yes & Yes & Yes & Yes & Yes \\
\hline Industry dummy & & Yes & Yes & Yes & Yes & Yes & Yes \\
\hline Country dummy & & Yes & Yes & Yes & Yes & Yes & Yes \\
\hline Pseudo - R2 & & 0.0846 & & 0.0905 & & 0.0751 & \\
\hline
\end{tabular}

Standard errors in parentheses; ${ }^{* *} \mathrm{p}<0.01,{ }^{* *} \mathrm{p}<0.05,{ }^{*} \mathrm{p}<0.1$; Notes: II $=$ Institutional Investors; Mg. $=$ marginal; EMBI is expressed in base points 
Table 6 - Institutional Ownership Shares by investor heterogeneity

Random Effects Regressions - firm, industry and country fixed effects

Dependent variable: institutional ownership equity shares

\begin{tabular}{|c|c|c|c|c|}
\hline & & $\begin{array}{l}\text { Total } \\
\text { IOWN }\end{array}$ & $\begin{array}{c}\text { Grey } \\
\text { Investors }\end{array}$ & $\begin{array}{c}\text { Indep. } \\
\text { Investors }\end{array}$ \\
\hline VARIABLE & & Col.1 & Col.2 & Col.3 \\
\hline \multicolumn{5}{|l|}{ Board Variables } \\
\hline Outsiders in the board & B1 & $\begin{array}{r}0.0887^{* *} \\
(0.039)\end{array}$ & $\begin{array}{r}0.0215^{*} \\
(0.012)\end{array}$ & $\begin{array}{l}0.0410 \\
(0.038)\end{array}$ \\
\hline Board turnover ratio & B2 & $\begin{array}{l}0.0084 \\
(0.023)\end{array}$ & $\begin{array}{r}-0.0051 \\
(0.007)\end{array}$ & $\begin{array}{l}0.0084 \\
(0.021)\end{array}$ \\
\hline CEO of the firm is also de COB (Dummy) & B3 & $\begin{array}{r}0.0374 * * * \\
(0.013)\end{array}$ & $\begin{array}{l}0.0058 \\
(0.004)\end{array}$ & $\begin{array}{l}0.0061 \\
(0.013)\end{array}$ \\
\hline Women in the Board & B4 & $\begin{array}{r}-0.1115^{* *} \\
(0.050)\end{array}$ & $\begin{array}{r}0.0283^{*} \\
(0.015)\end{array}$ & $\begin{array}{r}-0.1281^{* * *} \\
(0.049)\end{array}$ \\
\hline Foreigners in the board & B5 & $\begin{array}{l}0.0184 \\
(0.029)\end{array}$ & $\begin{array}{r}0.0194^{* *} \\
(0.009)\end{array}$ & $\begin{array}{r}-0.0162 \\
(0.028)\end{array}$ \\
\hline Board members with a master's degree & B6 & $\begin{array}{l}0.0080 \\
(0.035)\end{array}$ & $\begin{array}{r}0.0323^{* * *} \\
(0.011)\end{array}$ & $\begin{array}{l}0.0226 \\
(0.034)\end{array}$ \\
\hline Undergraduate studies in non business or & B7 & $\begin{array}{r}-0.0085 \\
(0.035)\end{array}$ & $\begin{array}{r}-0.0015 \\
(0.011)\end{array}$ & $\begin{array}{r}-0.0500 \\
(0.034)\end{array}$ \\
\hline Director CEO experience & B8 & $\begin{array}{r}-0.0321 \\
(0.034)\end{array}$ & $\begin{array}{r}-0.0063 \\
(0.010)\end{array}$ & $\begin{array}{l}0.0126 \\
(0.033)\end{array}$ \\
\hline Director founder experience & B9 & $\begin{array}{l}0.0591 \\
(0.072)\end{array}$ & $\begin{array}{l}0.0176 \\
(0.022)\end{array}$ & $\begin{array}{r}0.1373^{*} \\
(0.071)\end{array}$ \\
\hline Directors public sector experience & B10 & $\begin{array}{r}-0.0152 \\
(0.071) \\
\end{array}$ & $\begin{array}{l}0.0304 \\
(0.022) \\
\end{array}$ & $\begin{array}{r}-0.1424^{* *} \\
(0.068) \\
\end{array}$ \\
\hline \multicolumn{5}{|l|}{ Ownership } \\
\hline Wedge & B11 & $\begin{array}{r}0.0596^{* * *} \\
(0.014)\end{array}$ & $\begin{array}{l}0.0048 \\
(0.004)\end{array}$ & $\begin{array}{r}0.0455^{* * *} \\
(0.013)\end{array}$ \\
\hline Herfindahl Concentration Index & B12 & $\begin{array}{r}0.0813^{* * *} \\
(0.021)\end{array}$ & $\begin{array}{r}-0.0088 \\
(0.007)\end{array}$ & $\begin{array}{r}0.1918^{* * * *} \\
(0.021)\end{array}$ \\
\hline Second Shareholder equity rights & B13 & $\begin{array}{r}0.2965^{* * *} \\
(0.045) \\
\end{array}$ & $\begin{array}{r}0.0436^{* * *} \\
(0.014) \\
\end{array}$ & $\begin{array}{r}0.3119 * * * \\
(0.043) \\
\end{array}$ \\
\hline \multicolumn{5}{|l|}{ Firm Financial } \\
\hline Return On Assets (ROA) & B14 & $\begin{array}{l}0.0371 \\
(0.030)\end{array}$ & $\begin{array}{r}-0.0047 \\
(0.010)\end{array}$ & $\begin{array}{l}0.0466 \\
(0.029)\end{array}$ \\
\hline Operating Income Volatility & B15 & $\begin{array}{r}4.32 \mathrm{E}-05 \\
(0.000)\end{array}$ & $\begin{array}{r}-2.56 \mathrm{E}-06 \\
(0.000)\end{array}$ & $\begin{array}{r}3.83 \mathrm{E}-05^{* * *} \\
(0.000)\end{array}$ \\
\hline Firm Size (Natural logarithm of total assets) & B16 & $\begin{array}{r}-0.0077 \\
(0.005)\end{array}$ & $\begin{array}{l}0.0009 \\
(0.001)\end{array}$ & $\begin{array}{r}-0.0137^{* * *} \\
(0.005)\end{array}$ \\
\hline Firm Beta & B17 & $\begin{array}{l}0.0058 \\
(0.007)\end{array}$ & $\begin{array}{r}-0.0003 \\
(0.002)\end{array}$ & $\begin{array}{l}0.0050 \\
(0.007)\end{array}$ \\
\hline Asset Tangibility & B18 & $\begin{array}{r}-0.0257 \\
(0.024) \\
\end{array}$ & $\begin{array}{r}0.0157^{* *} \\
(0.007) \\
\end{array}$ & $\begin{array}{r}-0.0559 * * \\
(0.023) \\
\end{array}$ \\
\hline
\end{tabular}


Table 6 - Institutional Ownership Shares by investor heterogeneity (Cont.)

Random Effects Regressions - firm, industry and country fixed effects

Dependent variable: institutional ownership equity shares

\begin{tabular}{|c|c|c|c|c|}
\hline & & $\begin{array}{l}\text { Total } \\
\text { IOWN }\end{array}$ & $\begin{array}{c}\text { Grey } \\
\text { Investors }\end{array}$ & $\begin{array}{l}\text { Indep. } \\
\text { Investors }\end{array}$ \\
\hline VARIABLE & & Col.1 & Col.2 & Col.3 \\
\hline \multicolumn{5}{|l|}{ Market and Macro Variables } \\
\hline Stock Turnover Dummy (P75) & B19 & $\begin{array}{c}-0.0092 \\
(0.008)\end{array}$ & $\begin{array}{r}-0.0099 * * * \\
(0.003)\end{array}$ & $\begin{array}{r}-0.0113 \\
(0.008)\end{array}$ \\
\hline Property Rights Index & B20 & $\begin{array}{r}-0.0928 \\
(0.069)\end{array}$ & $\begin{array}{r}-0.0279 \\
(0.023)\end{array}$ & $\begin{array}{r}-0.0773 \\
(0.065)\end{array}$ \\
\hline EMBI & B21 & $\begin{array}{r}-0.0228 \\
(0.060)\end{array}$ & $\begin{array}{r}-0.0379 * \\
(0.020)\end{array}$ & $\begin{array}{l}0.0320 \\
(0.057)\end{array}$ \\
\hline Market Capitalization (\% of GDP) & B22 & $\begin{array}{r}-2.99 \mathrm{E}-04 \\
(0.000)\end{array}$ & $\begin{array}{r}-1.24 \mathrm{E} 04^{*} \\
(0.000)\end{array}$ & $\begin{array}{r}-2.09 \mathrm{E}-04 \\
(0.000)\end{array}$ \\
\hline Constant & & $\begin{array}{l}0.0952 \\
(0.078) \\
\end{array}$ & $\begin{array}{r}0.0287 \\
(0.023) \\
\end{array}$ & $\begin{array}{r}0.1472^{*} \\
(0.082) \\
\end{array}$ \\
\hline \multicolumn{5}{|l|}{ Regression Statistics } \\
\hline Observations & & 3,563 & 3,563 & 3,563 \\
\hline Number of id_firm_n & & 387 & 387 & 387 \\
\hline r2_overall & & 0.0853 & 0.0242 & 0.0964 \\
\hline r2_between & & 0.115 & 0.0418 & 0.119 \\
\hline r2_within & & 0.0414 & 0.0268 & 0.0582 \\
\hline chi2 & & 183.7 & 100.6 & 243.5 \\
\hline p-value & & {$[0.000]$} & {$[0.000]$} & {$[0.000]$} \\
\hline Lagrange test Pooled vs RE Model & & 5,814 & 5,260 & 7,497 \\
\hline$p$-value & & {$[0.000]$} & {$[0.000]$} & {$[0.000]$} \\
\hline Hausman Test - RE model is efficient & & 39.86 & 15.78 & 34.43 \\
\hline $\mathrm{p}$-value & & [0.1323] & [0.9893] & [0.2639] \\
\hline \multicolumn{5}{|l|}{ Fixed effects dummies } \\
\hline Industry dummy & & Yes & Yes & Yes \\
\hline Country dummy & & Yes & Yes & Yes \\
\hline Year dummy & & Yes & Yes & Yes \\
\hline
\end{tabular}

*** $\mathrm{p}<0.01,{ }^{* *} \mathrm{p}<0.05,{ }^{*} \mathrm{p}<0.1$

Notes: Board variables are ratios otherwise stated; EMBI is expressed in original units - i.e., 0.01 instead of 100 base points-; Standard errors in parentheses, p-values in brackets; 
Table 7 - Robustness Analysis - Total institutional ownership

Perfect identified and over-identified IV systems

Dependent variable: institutional investor shares (shares)

\begin{tabular}{|c|c|c|c|c|c|c|}
\hline VARIABLES & & $\begin{array}{c}\mathrm{m}=0 \\
\mathrm{RE} \\
\text { Col.1 }\end{array}$ & $\begin{array}{c}\mathrm{m}=2 \\
\mathrm{G} 2 \mathrm{LS}-\mathrm{RE} \\
\text { Col.2 }\end{array}$ & $\begin{array}{l}\mathrm{m}=1 \\
\text { IV } \\
\text { Col.3 }\end{array}$ & $\begin{array}{c}\mathrm{m}=2 \\
\text { IV } \\
\text { Col.4 }\end{array}$ & $\begin{array}{c}\mathrm{m}=2 \\
\text { IV } \\
\text { Col.5 }\end{array}$ \\
\hline \multicolumn{7}{|l|}{ Board Variables } \\
\hline Outsiders in the board (ratio) & B1 & $\begin{array}{c}0.0931 * \\
(0.055)\end{array}$ & $\begin{array}{c}0.1039 * * \\
(0.041)\end{array}$ & $\begin{array}{c}0.0694^{* *} \\
(0.027)\end{array}$ & $\begin{array}{c}0.0705^{* * *} \\
(0.027)\end{array}$ & $\begin{array}{c}0.0648^{* *} \\
(0.028)\end{array}$ \\
\hline Board_turnover ratio & B2 & $\begin{array}{l}0.0041 \\
(0.023)\end{array}$ & $\begin{array}{l}0.0057 \\
(0.023)\end{array}$ & $\begin{array}{l}-0.0277 \\
(0.033)\end{array}$ & $\begin{array}{c}-0.0296 \\
(0.033)\end{array}$ & $\begin{array}{r}-0.0289 \\
(0.034)\end{array}$ \\
\hline CEO of the firm is also de COB (Dummy) & B3 & $\begin{array}{c}0.0370 * \\
(0.022)\end{array}$ & $\begin{array}{c}0.0389 * * * \\
(0.014)\end{array}$ & $\begin{array}{l}0.0179 \\
(0.013)\end{array}$ & $\begin{array}{l}0.0152 \\
(0.011)\end{array}$ & $\begin{array}{l}0.0141 \\
(0.013)\end{array}$ \\
\hline Women in the Board (ratio) & B4 & $\begin{array}{c}-0.1158^{* *} \\
(0.052)\end{array}$ & $\begin{array}{c}-0.1194^{* *} \\
(0.051)\end{array}$ & $\begin{array}{c}-0.0924^{* * *} \\
(0.033)\end{array}$ & $\begin{array}{c}-0.0879 * * * \\
(0.031)\end{array}$ & $\begin{array}{c}-0.0722^{* *} \\
(0.034)\end{array}$ \\
\hline Foreigners in the board (ratio) & B5 & $\begin{array}{c}0.0213 \\
(0.041)\end{array}$ & $\begin{array}{l}0.0196 \\
(0.029)\end{array}$ & $\begin{array}{l}0.0239 \\
(0.026)\end{array}$ & $\begin{array}{l}0.0307 \\
(0.023)\end{array}$ & $\begin{array}{l}0.0380 \\
(0.030)\end{array}$ \\
\hline Board members with a MSc. degree (ratio) & B6 & $\begin{array}{l}0.0096 \\
(0.044)\end{array}$ & $\begin{array}{l}0.0017 \\
(0.036)\end{array}$ & $\begin{array}{c}0.0804 * * * \\
(0.029)\end{array}$ & $\begin{array}{c}0.0860 * * * \\
(0.027)\end{array}$ & $\begin{array}{c}0.0917^{* * *} \\
(0.031)\end{array}$ \\
\hline \multicolumn{7}{|l|}{ Undergraduate studies in non business or law } \\
\hline related fields (ratio) & B7 & $\begin{array}{l}-0.0073 \\
(0.051)\end{array}$ & $\begin{array}{l}-0.0108 \\
(0.036)\end{array}$ & $\begin{array}{c}-0.0643^{* * *} \\
(0.024)\end{array}$ & $\begin{array}{c}-0.0670 * * * \\
(0.023)\end{array}$ & $\begin{array}{c}-0.0713^{* * * *} \\
(0.024)\end{array}$ \\
\hline Board Members with CEO experience & B8 & $\begin{array}{l}-0.0260 \\
(0.054)\end{array}$ & $\begin{array}{l}-0.0284 \\
(0.034)\end{array}$ & $\begin{array}{l}0.0049 \\
(0.024)\end{array}$ & $\begin{array}{l}0.0046 \\
(0.023)\end{array}$ & $\begin{array}{l}0.0046 \\
(0.024)\end{array}$ \\
\hline Board Members_founders (ratio) & B9 & $\begin{array}{l}0.0582 \\
(0.127)\end{array}$ & $\begin{array}{l}0.1152 \\
(0.081)\end{array}$ & $\begin{array}{l}0.0204 \\
(0.056)\end{array}$ & $\begin{array}{l}0.0169 \\
(0.049)\end{array}$ & $\begin{array}{l}-0.0030 \\
(0.056)\end{array}$ \\
\hline Directors public high profile (ratio) & B10 & $\begin{array}{r}-0.0229 \\
(0.116) \\
\end{array}$ & $\begin{array}{r}-0.0524 \\
(0.074) \\
\end{array}$ & $\begin{array}{c}-0.1412^{* * *} \\
(0.053)\end{array}$ & $\begin{array}{c}-0.1459 * * * \\
(0.052)\end{array}$ & $\begin{array}{c}-0.1502^{* * *} \\
(0.054) \\
\end{array}$ \\
\hline \multicolumn{7}{|l|}{ Ownership } \\
\hline Wedge & B11 & $\begin{array}{c}0.0596^{* *} \\
(0.023)\end{array}$ & $\begin{array}{c}0.0600^{* * *} \\
(0.014)\end{array}$ & $\begin{array}{l}0.0090 \\
(0.013)\end{array}$ & $\begin{array}{l}0.0086 \\
(0.013)\end{array}$ & $\begin{array}{l}0.0076 \\
(0.013)\end{array}$ \\
\hline Herfindahl Concentration Index & B12 & $\begin{array}{c}0.0796^{*} \\
(0.043)\end{array}$ & $\begin{array}{c}0.0836^{* * *} \\
(0.022)\end{array}$ & $\begin{array}{l}0.0222 \\
(0.024)\end{array}$ & $\begin{array}{l}0.0341 \\
(0.021)\end{array}$ & $\begin{array}{l}0.0434 \\
(0.027)\end{array}$ \\
\hline Second Shareholder Participation (\%) & B13 & $\begin{array}{c}0.2995^{* * *} \\
(0.085) \\
\end{array}$ & $\begin{array}{c}0.2954^{* * *} \\
(0.046) \\
\end{array}$ & $\begin{array}{c}0.3282^{* * *} \\
(0.046) \\
\end{array}$ & $\begin{array}{c}0.3282^{* * *} \\
(0.044)\end{array}$ & $\begin{array}{c}0.3266^{* * *} \\
(0.048) \\
\end{array}$ \\
\hline \multicolumn{7}{|l|}{ Firm Financial } \\
\hline Return On Assets (ROA) & B14 & $\begin{array}{l}0.0431 \\
(0.034)\end{array}$ & $\begin{array}{l}0.3467 \\
(0.213)\end{array}$ & $\begin{array}{l}0.2882 \\
(0.348)\end{array}$ & $\begin{array}{l}0.1877 \\
(0.231)\end{array}$ & $\begin{array}{l}0.0596 \\
(0.382)\end{array}$ \\
\hline Operating Income Volatility & B15 & $\begin{array}{l}0.0000 \\
(0.000)\end{array}$ & $\begin{array}{c}0.0000 * * * \\
(0.000)\end{array}$ & $\begin{array}{l}-0.0000 \\
(0.000)\end{array}$ & $\begin{array}{l}-0.0000 \\
(0.000)\end{array}$ & $\begin{array}{l}-0.0000 \\
(0.000)\end{array}$ \\
\hline Firm Size (Natural logarithm of total assets) & B16 & $\begin{array}{l}-0.0099 \\
(0.007)\end{array}$ & $\begin{array}{c}-0.0076 \\
(0.005)\end{array}$ & $\begin{array}{l}-0.0010 \\
(0.004)\end{array}$ & $\begin{array}{l}-0.0003 \\
(0.003)\end{array}$ & $\begin{array}{l}0.0008 \\
(0.004)\end{array}$ \\
\hline Firm Beta & B17 & $\begin{array}{l}0.0038 \\
(0.007)\end{array}$ & $\begin{array}{l}0.0041 \\
(0.007)\end{array}$ & $\begin{array}{l}0.0001 \\
(0.008)\end{array}$ & $\begin{array}{l}0.0004 \\
(0.007)\end{array}$ & $\begin{array}{l}-0.0007 \\
(0.008)\end{array}$ \\
\hline Tangibility (Total PPE / total assets) & B18 & $\begin{array}{c}-0.0208 \\
(0.028) \\
\end{array}$ & $\begin{array}{r}-0.0143 \\
(0.025) \\
\end{array}$ & $\begin{array}{c}-0.0964^{* * *} \\
(0.020) \\
\end{array}$ & $\begin{array}{c}-0.1016^{* * *} \\
(0.019) \\
\end{array}$ & $\begin{array}{c}-0.0961 * * * \\
(0.021)\end{array}$ \\
\hline
\end{tabular}


Table 7 - Robustness Analysis - Total institutional ownership (Cont)

Perfect identified and over-identified IV systems

Dependent variable: institutional investor shares (shares)

\begin{tabular}{|c|c|c|c|c|c|c|}
\hline VARIABLES & & $\begin{array}{c}\mathrm{m}=0 \\
\mathrm{RE} \\
\text { Col.1 } \\
\end{array}$ & $\begin{array}{c}\mathrm{m}=2 \\
\mathrm{G} 2 \mathrm{LS}-\mathrm{RE} \\
\mathrm{Col} .2\end{array}$ & $\begin{array}{c}\mathrm{m}=1 \\
\mathrm{IV} \\
\mathrm{Col} .3 \\
\end{array}$ & $\begin{array}{c}\mathrm{m}=2 \\
\mathrm{IV} \\
\text { Col.4 }\end{array}$ & $\begin{array}{c}\mathrm{m}=2 \\
\mathrm{IV} \\
\text { Col.5 }\end{array}$ \\
\hline \multicolumn{7}{|l|}{ Market and Macro Variables } \\
\hline Turnover p75. (Dummy) & B19 & $\begin{array}{l}-0.0074 \\
(0.011)\end{array}$ & $\begin{array}{l}-0.0067 \\
(0.008)\end{array}$ & $\begin{array}{l}0.0116 \\
(0.009)\end{array}$ & $\begin{array}{l}0.0119 \\
(0.009)\end{array}$ & $\begin{array}{l}0.0116 \\
(0.010)\end{array}$ \\
\hline Property Rights & B20 & $\begin{array}{c}-0.1990 * * \\
(0.078)\end{array}$ & $\begin{array}{c}-0.1904^{* * *} \\
(0.061)\end{array}$ & $\begin{array}{c}-0.1942 * * \\
(0.084)\end{array}$ & $\begin{array}{c}-0.2095^{* *} \\
(0.082)\end{array}$ & $\begin{array}{c}-0.2568 * * * \\
(0.092)\end{array}$ \\
\hline m_embi & B21 & $\begin{array}{l}-0.0551 \\
(0.060)\end{array}$ & $\begin{array}{l}-0.0581 \\
(0.056)\end{array}$ & $\begin{array}{c}-0.1125^{*} \\
(0.064)\end{array}$ & $\begin{array}{c}-0.1208^{*} \\
(0.063)\end{array}$ & $\begin{array}{c}-0.1103^{*} \\
(0.066)\end{array}$ \\
\hline Market Capitalization (\% of GDP) & B22 & $\begin{array}{l}-0.0000 \\
(0.000)\end{array}$ & $\begin{array}{l}0.0000 \\
(0.000)\end{array}$ & $\begin{array}{c}-0.0001 \\
(0.000)\end{array}$ & $\begin{array}{c}-0.0002 \\
(0.000)\end{array}$ & $\begin{array}{l}-0.0001 \\
(0.000)\end{array}$ \\
\hline Constant & & $\begin{array}{l}0.1422 \\
(0.096) \\
\end{array}$ & $\begin{array}{l}0.0652 \\
(0.094) \\
\end{array}$ & $\begin{array}{c}0.1958^{* * *} \\
(0.058)\end{array}$ & $\begin{array}{c}0.2137^{* * *} \\
(0.052) \\
\end{array}$ & $\begin{array}{c}0.2341^{* * *} \\
(0.059) \\
\end{array}$ \\
\hline \multicolumn{7}{|l|}{ Regression Statistics } \\
\hline Observations & & 3,563 & 3,519 & 3,563 & 3,519 & 3,276 \\
\hline Number of id_firm_n & & 387 & 386 & $\ldots$ & $\ldots$ & $\ldots$ \\
\hline R2 & & 0.0836 & 0.0761 & 0.0956 & 0.107 & 0.105 \\
\hline R2-between & & 0.116 & 0.112 & $\ldots$ & $\ldots$ & $\ldots$ \\
\hline R2-within & & 0.0359 & 0.0208 & $\ldots$ & $\ldots$ & $\ldots$ \\
\hline Chi Stat & & 91.96 & 165.3 & $\ldots$ & $\ldots$ & $\ldots$ \\
\hline Chi2-p-value & & [0.000] & {$[0.000]$} & $\ldots$ & $\ldots$ & $\ldots$ \\
\hline F Stat & & $\ldots$ & $\ldots$ & 16.52 & 17.13 & 15.19 \\
\hline F stat $p$-value & & $\ldots$ & $\ldots$ & {$[0.000]$} & {$[0.000]$} & {$[0.000]$} \\
\hline \multicolumn{7}{|l|}{ Test on Instruments } \\
\hline Hansen J-Test & & $\ldots$ & $\ldots$ & 0 & 0.132 & 2.065 \\
\hline Hansen-p-value & & $\ldots$ & $\ldots$ & $\ldots$ & 0.716 & 0.151 \\
\hline Endogeneity test & & $\ldots$ & $\ldots$ & 0.488 & 0.41 & 0.00622 \\
\hline Endog - p-Value & & $\ldots$ & $\ldots$ & [0.485] & [0.522] & '[0.937] \\
\hline Underidentification & & $\ldots$ & $\ldots$ & 33.23 & 66.88 & 38.73 \\
\hline Under-p-value & & $\ldots$ & $\ldots$ & [0.000] & {$[0.000]$} & [0.000] \\
\hline F Stat - 1st-stage & & $\ldots$ & $\ldots$ & 33.68 & 31.33 & 17.37 \\
\hline
\end{tabular}

Notes: *** $\mathrm{p}<0.01, * * \mathrm{p}<0.05, * \mathrm{p}<0.1$

Robust standard errors in parentheses; $\mathrm{m}=$ the number of excluded instruments in the 2SLS; regressions include country and industry fixed effects. Instrumented Variable = ROA; Main Instruments: leverage ratio, growth opportunities and their first lags 
Table 8 - Institutional ownership and board dynamics (OLS Estimates)

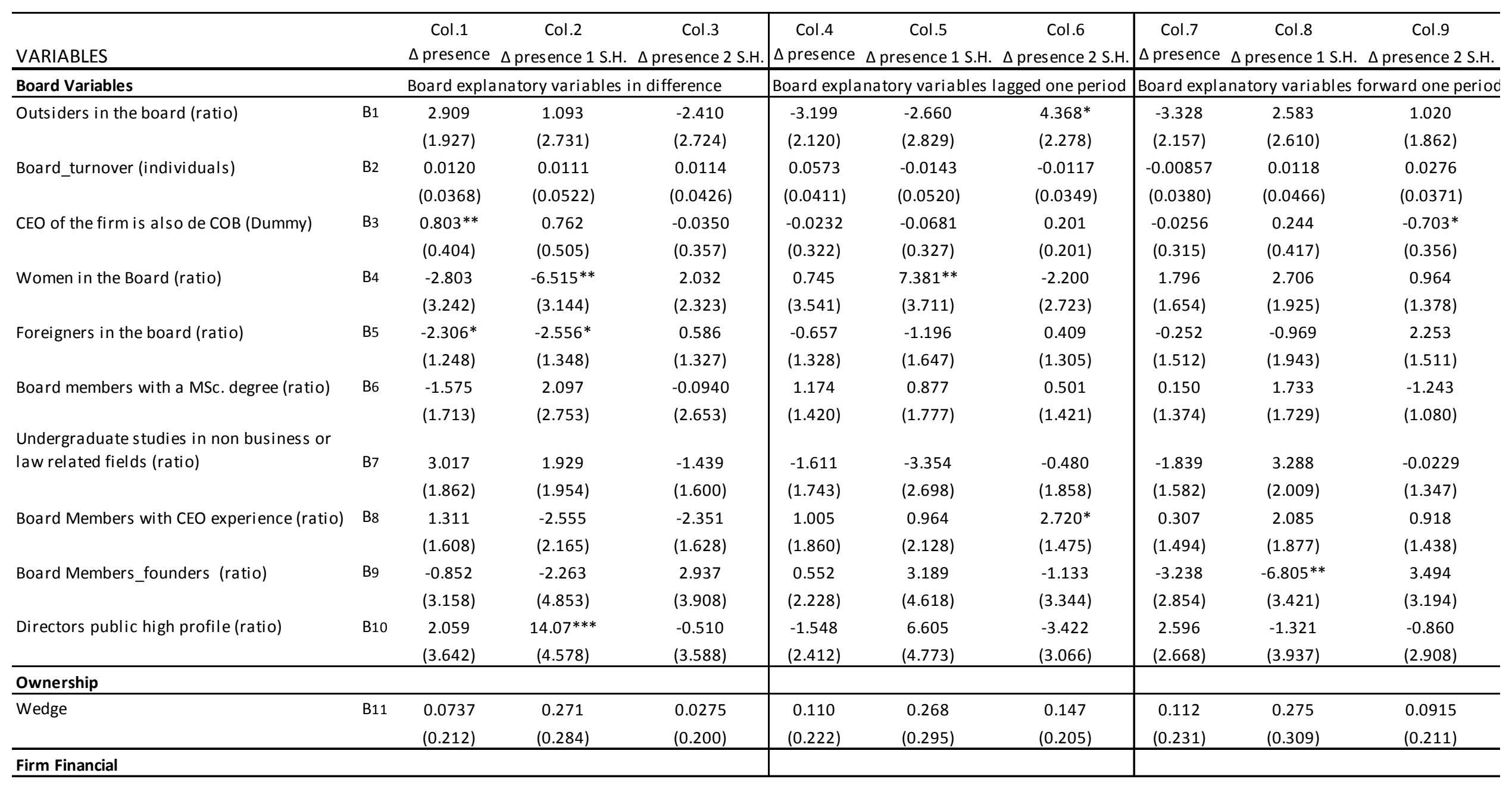


Table 8 - Institutional ownership and board dynamics (Cont.)

(OLS Estimates)

\begin{tabular}{|c|c|c|c|c|c|c|c|c|c|c|}
\hline VARIABLES & & $\begin{array}{c}\text { Col.1 } \\
\Delta \text { presence } \\
\end{array}$ & $\begin{array}{c}\text { Col.2 } \\
\Delta \text { presence 1 S.H. }\end{array}$ & $\begin{array}{c}\text { Col.3 } \\
\Delta \text { presence 2 S.H. }\end{array}$ & $\begin{array}{c}\text { Col.4 } \\
\Delta \text { presence } \\
\end{array}$ & $\begin{array}{c}\text { Col.5 } \\
\Delta \text { presence } 1 \mathrm{~S} . \mathrm{H} .\end{array}$ & $\begin{array}{c}\text { Col.6 } \\
\Delta \text { presence } 2 \text { S.H. }\end{array}$ & $\begin{array}{c}\text { Col.7 } \\
\Delta \text { presence } \\
\end{array}$ & $\begin{array}{c}\text { Col.8 } \\
\Delta \text { presence 1 S.H. }\end{array}$ & $\begin{array}{c}\text { Col.9 } \\
\Delta \text { presence 2 S.H. }\end{array}$ \\
\hline \multicolumn{11}{|l|}{ Firm Financial } \\
\hline Return On Assets (ROA) & B12 & $\begin{array}{c}0.274 \\
(0.761)\end{array}$ & $\begin{array}{l}0.0501 \\
(0.737)\end{array}$ & $\begin{array}{c}0.380 \\
(0.476)\end{array}$ & $\begin{array}{c}0.698 \\
(0.833)\end{array}$ & $\begin{array}{l}-0.0875 \\
(0.797)\end{array}$ & $\begin{array}{c}0.290 \\
(0.502)\end{array}$ & $\begin{array}{c}0.594 \\
(0.803)\end{array}$ & $\begin{array}{c}0.752 \\
(0.798)\end{array}$ & $\begin{array}{c}0.377 \\
(0.505)\end{array}$ \\
\hline Leverage & B13 & $\begin{array}{l}0.0664 \\
(0.303)\end{array}$ & $\begin{array}{c}0.358 \\
(0.422)\end{array}$ & $\begin{array}{l}-0.442 \\
(0.295)\end{array}$ & $\begin{array}{l}0.0401 \\
(0.315)\end{array}$ & $\begin{array}{c}0.00443 \\
(0.454)\end{array}$ & $\begin{array}{l}-0.408 \\
(0.328)\end{array}$ & $\begin{array}{l}-0.0951 \\
(0.328)\end{array}$ & $\begin{array}{c}0.186 \\
(0.446)\end{array}$ & $\begin{array}{l}-0.299 \\
(0.307)\end{array}$ \\
\hline Firm Size (Natural logarithm of total assets) & B14 & $\begin{array}{l}-0.0471 \\
(0.0390)\end{array}$ & $\begin{array}{l}-0.00471 \\
(0.0457)\end{array}$ & $\begin{array}{l}0.00759 \\
(0.0319)\end{array}$ & $\begin{array}{l}-0.0803^{*} \\
(0.0417)\end{array}$ & $\begin{array}{l}-0.00783 \\
(0.0516)\end{array}$ & $\begin{array}{l}-0.00117 \\
(0.0365)\end{array}$ & $\begin{array}{l}-0.0498 \\
(0.0418)\end{array}$ & $\begin{array}{c}0.0102 \\
(0.0527)\end{array}$ & $\begin{array}{c}0.0179 \\
(0.0376)\end{array}$ \\
\hline Firm Beta & B15 & $\begin{array}{l}0.0838 \\
(0.201)\end{array}$ & $\begin{array}{l}0.0836 \\
(0.179)\end{array}$ & $\begin{array}{l}0.0294 \\
(0.115)\end{array}$ & $\begin{array}{c}0.106 \\
(0.216)\end{array}$ & $\begin{array}{l}-0.108 \\
(0.197)\end{array}$ & $\begin{array}{l}0.0477 \\
(0.124)\end{array}$ & $\begin{array}{c}0.112 \\
(0.218)\end{array}$ & $\begin{array}{c}-0.000591 \\
(0.190)\end{array}$ & $\begin{array}{l}-0.0101 \\
(0.116)\end{array}$ \\
\hline Tangibility (Total PPE / total assets) & B16 & $\begin{array}{l}0.0646 \\
(0.282) \\
\end{array}$ & $\begin{array}{r}0.300 \\
(0.373) \\
\end{array}$ & $\begin{array}{r}-0.214 \\
(0.260) \\
\end{array}$ & $\begin{array}{c}0.152 \\
(0.299) \\
\end{array}$ & $\begin{array}{r}0.608 \\
(0.405) \\
\end{array}$ & $\begin{array}{r}-0.123 \\
(0.288) \\
\end{array}$ & $\begin{array}{l}0.0922 \\
(0.294) \\
\end{array}$ & $\begin{array}{r}0.0164 \\
(0.420) \\
\end{array}$ & $\begin{array}{r}-0.166 \\
(0.295) \\
\end{array}$ \\
\hline \multicolumn{11}{|l|}{ Market and Macro Variables } \\
\hline Stock Turnover p75. (Dummy) & B17 & $\begin{array}{l}0.0614 \\
(0.142)\end{array}$ & $\begin{array}{l}0.0646 \\
(0.185)\end{array}$ & $\begin{array}{l}-0.0968 \\
(0.134)\end{array}$ & $\begin{array}{c}0.00547 \\
(0.145)\end{array}$ & $\begin{array}{c}-0.00142 \\
(0.204)\end{array}$ & $\begin{array}{l}-0.0659 \\
(0.143)\end{array}$ & $\begin{array}{l}0.0175 \\
(0.152)\end{array}$ & $\begin{array}{l}0.0186 \\
(0.194)\end{array}$ & $\begin{array}{l}-0.124 \\
(0.133)\end{array}$ \\
\hline Emerging Markets Bond Index (EMBI) & B18 & $\begin{array}{c}3.32 \mathrm{e}-05 \\
(1.80 \mathrm{e}-04)\end{array}$ & $\begin{array}{l}-4.26 \mathrm{E}-04 \\
(4.32 \mathrm{e}-04)\end{array}$ & $\begin{array}{r}-3.12 \mathrm{E}-04 \\
(2.78 \mathrm{e}-04)\end{array}$ & $\begin{array}{c}1.29 \mathrm{E}-04 \\
(1.84 \mathrm{e}-04)\end{array}$ & $\begin{array}{c}2.99 \mathrm{E}-04 \\
(7.17 \mathrm{e}-04)\end{array}$ & $\begin{array}{c}-5.54 \mathrm{E}-04 \\
(4.75 \mathrm{e}-04)\end{array}$ & $\begin{array}{c}4.51 \mathrm{E}-05 \\
(1.95 \mathrm{e}-04)\end{array}$ & $\begin{array}{c}-4.20 \mathrm{E}-04 \\
(4.56 \mathrm{e}-04)\end{array}$ & $\begin{array}{c}-2.18 \mathrm{E}-04 \\
(2.93 \mathrm{e}-04)\end{array}$ \\
\hline Market Capitalization (\% of GDP) & B19 & $\begin{array}{c}-0.00773^{* * *} \\
(2.90 \mathrm{e}-03)\end{array}$ & $\begin{array}{c}-0.00837^{* *} \\
(3.89 \mathrm{e}-03)\end{array}$ & $\begin{array}{c}-0.00191 \\
(2.91 \mathrm{e}-03)\end{array}$ & $\begin{array}{l}-0.00944 * * * \\
(3.26 \mathrm{e}-03)\end{array}$ & $\begin{array}{c}-0.00917^{* *} \\
(4.46 \mathrm{e}-03)\end{array}$ & $\begin{array}{r}-0.000319 \\
(3.35 e-03)\end{array}$ & $\begin{array}{l}-0.00604 * \\
(3.11 \mathrm{e}-03)\end{array}$ & $\begin{array}{c}-0.00581 \\
(4.15 e-03)\end{array}$ & $\begin{array}{r}-0.000146 \\
(3.10 \mathrm{e}-03)\end{array}$ \\
\hline Property Rights & B20 & $\begin{array}{c}0.387 \\
(0.508)\end{array}$ & $\begin{array}{c}0.420 \\
(0.664)\end{array}$ & $\begin{array}{l}-0.227 \\
(0.468)\end{array}$ & $\begin{array}{c}0.749 \\
(0.587)\end{array}$ & $\begin{array}{c}0.435 \\
(0.799)\end{array}$ & $\begin{array}{l}-0.433 \\
(0.596)\end{array}$ & $\begin{array}{c}0.187 \\
(0.548)\end{array}$ & $\begin{array}{l}-0.417 \\
(0.733)\end{array}$ & $\begin{array}{l}-0.188 \\
(0.504)\end{array}$ \\
\hline Constant & & $\begin{array}{c}0.219 \\
(0.473) \\
\end{array}$ & $\begin{array}{c}-0.247 \\
(0.654) \\
\end{array}$ & $\begin{array}{c}0.591 \\
(0.470) \\
\end{array}$ & $\begin{array}{c}0.217 \\
(0.488)\end{array}$ & $\begin{array}{l}-0.115 \\
(0.757) \\
\end{array}$ & $\begin{array}{c}0.481 \\
(0.554) \\
\end{array}$ & $\begin{array}{c}0.241 \\
(0.506) \\
\end{array}$ & $\begin{array}{c}0.241 \\
(0.662) \\
\end{array}$ & $\begin{array}{c}0.178 \\
(0.471) \\
\end{array}$ \\
\hline Regression Statistics & & & & & & & & & & \\
\hline Observations & & 219 & 141 & 112 & 207 & 133 & 104 & 204 & 134 & 106 \\
\hline F-stat & & 1.671 & 1.827 & 0.676 & 1.392 & 1.124 & 0.707 & 0.950 & 1.277 & 0.862 \\
\hline R2 & & 0.144 & 0.233 & 0.129 & 0.130 & 0.167 & 0.145 & 0.0941 & 0.184 & 0.169 \\
\hline
\end{tabular}

Standard errors in parentheses; ${ }^{* * *} \mathrm{p}<0.01,{ }^{* *} \mathrm{p}<0.05$, $^{*} \mathrm{p}<0.1$ 


\section{Appendices}

Table A1: Variable definition

\begin{tabular}{ll}
\hline Variable & Definition \\
\hline Ownership & $\begin{array}{l}\text { Dummy equal to } 1 \text { if there is at least one institutional investor within the three major } \\
\text { shareholders }\end{array}$ \\
$\begin{array}{ll}\text { Institutional Investors precense } \\
\text { Institutional Investors shares }\end{array}$ & $\begin{array}{l}\text { Percentage of institutional investors shares within the three major shareholders } \\
\text { Dummy equal to } 1 \text { if there is at least one grey institutional investor within the three major }\end{array}$
\end{tabular}

Grey Institutional investors precence shareholders

Grey Institutional investors shares Percentage of grey institutional investors shares within the three major shareholders

Independent Institutional Investors Dummy equal to 1 if there is at least one independent institutional investor within the three precence

major shareholders

Source

Independent Institutional Investors

shares

Foreign Institutional Investors

presence

Percentage of independent institutional investors shares within the three major shareholders Anual Reports-Thomson Reuters Dummy equal to 1 if there is at least one foreign institutional investor within the three major

shareholders

Anual Reports-Thomson Reuters

Anual Reports-Thomson Reuters

Anual Reports-Thomson Reuters

Anual Reports-Thomson Reuters

Anual Reports-Thomson Reuters

Foreign Institutional Investors

shares

Local Institutional Investors

presence

Percentage of foreign institutional investors shares within the three major shareholders

Anual Reports-Thomson Reuters

Dummy equal to 1 if there is at least one local institutional investor within the three major

shareholders

Local Institutional Investors Shares Percentage of local institutional investors shares within the three major shareholders

Shapley Value

The Shapley Value solution for the largest shareholders in a three-voting game.

Degree of asymmetry between ownership and control for the largest shareholder. It is defined

as largest $\mathrm{BHL}$ equity rights to Shapley coalitional value

Anual Reports-Thomson Reuters

Anual Reports-Thomson Reuters

Anual Reports-Thomson Reuters

Anual Reports-Thomson Reuters

Own estimates

\section{Financial \\ ROA}

Firm Size

The ratio of net profits after tax to total assets

Natural Logarithm of total asssets

Leverage

The ratio of total liabilities to total assets

Stock Turnover

Annual average of daily trading volume (millions)/ \#Shares outstanding (millions)

Operating Income Volatility

Sales Growth

Standard deviation of the operating income for the last three years

Percentage of sales growth compared to previous year.

Standard measure of systemic risk for a firm's stock with respect to the market. It measures

Firm Beta

shares that have been traded for more than 180 days in a given year

Tangibility

Total property, plant and equipment divided by total assets

Anual Reports-Thomson Reuters

Anual Reports-Thomson Reuters

Anual Reports-Thomson Reuters

Anual Reports-Thomson Reuters

Anual Reports-Thomson Reuters

Anual Reports-Thomson Reuters

Anual Reports-Thomson Reuters

Anual Reports-Thomson Reuters 
Table A1- Variable definition (Cont.)

\section{Board of Directors}

Foreigners in the board (ratio)

Women in the Board (ratio)

Directors public high profile (ratio)

Board Members that are or were CEO firm), divided by the size of the board.

Board Members that were founders of corresponding firm), divided by the size of the board.

Board members with a master degree Number of board members with a master's degree, divided by the size of the board.

Number of people on the board with undergraduate studies that are not business or law

Undergraduate studies in non busines related, divided by the size of the board

Board Turnover

Represents the number of board members that left the board that year

CEO of the firm is also de COB (Dumm Dummy that indicates if the CEO of the firm is also the Chairman Of Board

Number of outside directors in the board divided by the size of the board. Outside director is

Outsiders in the board (ratio)

the one that doesn't have a contract or labors for the firm.

Between the 0 and 25th percentile: Dummy takes value of one if the board size is between the

Board Size Percentile 0 and 25 th percentile in that country.

Between the 75 and 100th percentile: Dummy takes value of one if the board size is between the 75 and 100th percentile in that country.

\section{Macroeconomic}

$\mathrm{EMBI}$

Property Rights Index
Emerging Markets Bonds Index. Measures financial risk in each country. Expressed in basis points

Is an assesmennt of the ability of individuals to accumulate private property, secured by clear laws that are fully enforced by the state. Index from 0 to 10.

Market capitalization (also known as market value) is the share price times the number of shares outstanding
Anual Reports-Thomson Reuters

Anual Reports-Thomson Reuters

Anual Reports-Thomson Reuters

Anual Reports-Thomson Reuters

Anual Reports-Thomson Reuters

Anual Reports-Thomson Reuters

Anual Reports-Thomson Reuters

Anual Reports-Thomson Reuters

Anual Reports-Thomson Reuters

Anual Reports-Thomson Reuters

Anual Reports-Thomson Reuters

Anual Reports-Thomson Reuters

Index of economic freedom

Standard \& Poor's, Global Stock

Markets Fact-book and supplemental S\&P data. 
Table A.2 -Descriptive statistics

Ownership, firm financial specific and macro variables included in the empirical model

Panel A - Ownership variables

\begin{tabular}{lcrrrr}
\hline Variable & Obs & Mean & \multicolumn{1}{l}{ Std. } & \multicolumn{1}{c}{ Min } & \multicolumn{1}{c}{ Max } \\
\hline Wedge ownership and control & 4,495 & 1.389 & 0.330 & 0 & 3.801 \\
Herfindal Index top 4 BHL & 4,498 & 0.329 & 0.252 & 0.003 & 1 \\
Equity rights 1st BHL & 4,498 & 0.481 & 0.246 & 0.031 & 1 \\
Equity rights 2nd BHL & 4,498 & 0.134 & 0.104 & 0 & 0.500 \\
Equity rights 3th BHL & 4,498 & 0.060 & 0.051 & 0 & 0.272 \\
Equity rights 4th BHL & 4,498 & 0.037 & 0.037 & 0 & 0.244 \\
Second blockholder equity share & 4,498 & 0.134 & 0.104 & 0 & 0.500 \\
Shapley Value & 4,495 & 0.680 & 0.354 & 0 & 1 \\
Institutional Shapley value & 1,739 & 0.305 & 0.373 & 0 & 1 \\
Absolute equity rigths dummy & 4,706 & 0.489 & 0.500 & 0 & 1 \\
\hline Panel B - Firm Financial Variables & & & & & \\
\hline Return on Assets & 4,458 & 0.121 & 0.119 & -0.774 & 1.449 \\
Leverage ratio & 4,513 & 0.478 & 0.210 & 0.005 & 1.358 \\
Firm size (Log Assets) & 4,513 & 6.099 & 1.854 & -0.258 & 12.650 \\
Sales_growth & 4,363 & 0.042 & 2.173 & -24.322 & 23.947 \\
Firm-stock beta & 4,031 & 0.108 & 0.426 & 0.000 & 7.736 \\
Asset Tangibility & 4,503 & 0.396 & 0.246 & 0.000 & 0.967 \\
Stock turnover-P75 & 4,441 & 0.261 & 0.439 & 0.000 & 1.000 \\
Operating Income Volatility & 4,314 & 74.4 & 302.8 & 0.0 & $6,540.1$ \\
\hline Panel C Macroeconomic variables & & & & & \\
\hline EMBI Index (Base points) & 4,702 & 467.9 & 777.8 & 64.9 & $5,741.7$ \\
Market Capitalization (Base $=100)$ & 4,702 & 59.1 & 35.1 & 9.8 & 157.0 \\
Property Rights Index & 4,702 & 0.611 & 0.234 & 0.222 & 1.000 \\
Legal Rights Index & 3,468 & 0.487 & 0.147 & 0.333 & 0.778 \\
GDP percapita growth & 4,702 & 3.992 & 3.124 & -10.890 & 9.800 \\
\hline
\end{tabular}

Source: Thomson Reuters World Scope and EIKON, Economatica, firm annual reports and WDI-World Bank 
Table A.3 - Instrumental variables regressions by investor heterogeneity

Robustness Analysis - Institutional Ownership by investor color

Perfect identified and over-identified IV systems

Dependent variable: institutional investor shares (shares)

\begin{tabular}{|c|c|c|c|c|c|c|}
\hline VARIABLES & $\begin{array}{c}\mathrm{m}=0 \\
\text { RE-Grey } \\
\text { Col.1 }\end{array}$ & $\begin{array}{c}m=2 \\
\text { 2GLS-RE-Grey } \\
\text { Col.2 }\end{array}$ & $\begin{array}{c}\mathrm{m}=2 \\
\text { IV-Grey } \\
\text { Col.3 } \\
\end{array}$ & $\begin{array}{c}\mathrm{m}=0 \\
\mathrm{RE}-\mathrm{Ind} \\
\text { Col.4 } \\
\end{array}$ & $\begin{array}{c}\mathrm{m}=2 \\
\text { 2GLS-RE-Ind } \\
\text { Col.5 } \\
\end{array}$ & $\begin{array}{c}\mathrm{m}=2 \\
\text { IV-Ind } \\
\text { Col.6 }\end{array}$ \\
\hline \multicolumn{7}{|l|}{ Board Variables } \\
\hline Outsiders in the board (ratio) & $\begin{array}{r}0.0190 * \\
(0.010)\end{array}$ & $\begin{array}{l}0.0144 \\
(0.013)\end{array}$ & $\begin{array}{r}0.0186^{* *} \\
(0.008)\end{array}$ & $\begin{array}{l}0.0326 \\
(0.073)\end{array}$ & $\begin{array}{l}0.0516 \\
(0.040)\end{array}$ & $\begin{array}{r}0.0590^{*} \\
(0.034)\end{array}$ \\
\hline bd_turnover ratio & $\begin{array}{r}-0.0020 \\
(0.006)\end{array}$ & $\begin{array}{r}-0.0039 \\
(0.007)\end{array}$ & $\begin{array}{l}0.0032 \\
(0.013)\end{array}$ & $\begin{array}{l}0.0162 \\
(0.022)\end{array}$ & $\begin{array}{l}0.0227 \\
(0.022)\end{array}$ & $\begin{array}{r}-0.0348 \\
(0.035)\end{array}$ \\
\hline CEO of the firm is also de COB (Dummy) & $\begin{array}{l}0.0059 \\
(0.009)\end{array}$ & $\begin{array}{l}0.0044 \\
(0.004)\end{array}$ & $\begin{array}{l}0.0034 \\
(0.004)\end{array}$ & $\begin{array}{l}0.0057 \\
(0.025)\end{array}$ & $\begin{array}{l}0.0088 \\
(0.014)\end{array}$ & $\begin{array}{l}0.0067 \\
(0.012)\end{array}$ \\
\hline Women in the Board (ratio) & $\begin{array}{l}0.0305 \\
(0.020)\end{array}$ & $\begin{array}{r}0.0291^{*} \\
(0.016)\end{array}$ & $\begin{array}{l}0.0105 \\
(0.007)\end{array}$ & $\begin{array}{r}-0.1241^{* *} \\
(0.063)\end{array}$ & $\begin{array}{r}-0.1295^{* * *} \\
(0.050)\end{array}$ & $\begin{array}{r}-0.0902 * * \\
(0.037)\end{array}$ \\
\hline Foreigners in the board (ratio) & $\begin{array}{r}0.0181^{*} \\
(0.011)\end{array}$ & $\begin{array}{r}0.0224 * * \\
(0.009)\end{array}$ & $\begin{array}{r}0.0193^{* * *} \\
(0.007)\end{array}$ & $\begin{array}{r}-0.0211 \\
(0.068)\end{array}$ & $\begin{array}{r}-0.0201 \\
(0.029)\end{array}$ & $\begin{array}{l}0.0397 \\
(0.025)\end{array}$ \\
\hline Board members with a master degree (ratio) & $\begin{array}{r}0.0345^{* *} \\
(0.014)\end{array}$ & $\begin{array}{r}0.0409 * * * \\
(0.012)\end{array}$ & $\begin{array}{r}0.0483^{* * *} \\
(0.009)\end{array}$ & $\begin{array}{l}0.0275 \\
(0.048)\end{array}$ & $\begin{array}{l}0.0144 \\
(0.036)\end{array}$ & $\begin{array}{l}0.0179 \\
(0.028)\end{array}$ \\
\hline \multicolumn{7}{|l|}{ Undergraduate studies in non business or law } \\
\hline related fields (ratio) & $\begin{array}{r}-0.0019 \\
(0.012)\end{array}$ & $\begin{array}{r}-0.0005 \\
(0.011)\end{array}$ & $\begin{array}{r}-0.0165 * * \\
(0.007)\end{array}$ & $\begin{array}{r}-0.0515 \\
(0.053)\end{array}$ & $\begin{array}{r}-0.0567 \\
(0.035)\end{array}$ & $\begin{array}{r}-0.0846^{* * *} \\
(0.025)\end{array}$ \\
\hline Board Members that are or were CEO (ratio) & $\begin{array}{r}-0.0053 \\
(0.011)\end{array}$ & $\begin{array}{r}-0.0064 \\
(0.011)\end{array}$ & $\begin{array}{r}0.0144^{* *} \\
(0.007)\end{array}$ & $\begin{array}{l}0.0213 \\
(0.053)\end{array}$ & $\begin{array}{l}0.0197 \\
(0.033)\end{array}$ & $\begin{array}{r}-0.0054 \\
(0.024)\end{array}$ \\
\hline Board Members that were founders (ratio) & $\begin{array}{l}0.0180 \\
(0.027)\end{array}$ & $\begin{array}{l}0.0079 \\
(0.026)\end{array}$ & $\begin{array}{r}-0.0279 * * * \\
(0.010)\end{array}$ & $\begin{array}{l}0.1385 \\
(0.138)\end{array}$ & $\begin{array}{r}0.2236^{* * *} \\
(0.080)\end{array}$ & $\begin{array}{r}0.2435^{* * *} \\
(0.060)\end{array}$ \\
\hline Directors public high profile (ratio) & $\begin{array}{l}0.0306 \\
(0.043) \\
\end{array}$ & $\begin{array}{r}0.0423^{*} \\
(0.024) \\
\end{array}$ & $\begin{array}{r}-0.0422^{* *} \\
(0.018) \\
\end{array}$ & $\begin{array}{r}-0.1510 \\
(0.123) \\
\end{array}$ & $\begin{array}{r}-0.1902^{* * *} \\
(0.073) \\
\end{array}$ & $\begin{array}{r}-0.1196 * * \\
(0.055) \\
\end{array}$ \\
\hline \multicolumn{7}{|l|}{ Ownership } \\
\hline Wedge & $\begin{array}{l}0.0052 \\
(0.010)\end{array}$ & $\begin{array}{l}0.0056 \\
(0.004)\end{array}$ & $\begin{array}{l}0.0041 \\
(0.005)\end{array}$ & $\begin{array}{r}0.0458 * * \\
(0.023)\end{array}$ & $\begin{array}{r}0.0468 * * * \\
(0.013)\end{array}$ & $\begin{array}{r}-0.0142 \\
(0.013)\end{array}$ \\
\hline Herfindahl Concentration Index & $\begin{array}{r}-0.0068 \\
(0.012)\end{array}$ & $\begin{array}{r}-0.0078 \\
(0.007)\end{array}$ & $\begin{array}{l}0.0025 \\
(0.007)\end{array}$ & $\begin{array}{r}0.1953^{* * *} \\
(0.064)\end{array}$ & $\begin{array}{r}0.2045^{* * *} \\
(0.021)\end{array}$ & $\begin{array}{r}0.1432^{* * *} \\
(0.024)\end{array}$ \\
\hline Second Shareholder Participation (\%) & $\begin{array}{l}0.0443 \\
(0.030) \\
\end{array}$ & $\begin{array}{r}0.0450 * * * \\
(0.015) \\
\end{array}$ & $\begin{array}{r}0.0396^{* * *} \\
(0.013) \\
\end{array}$ & $\begin{array}{r}0.3127^{* * *} \\
(0.103) \\
\end{array}$ & $\begin{array}{r}0.3095^{* * *} \\
(0.045) \\
\end{array}$ & $\begin{array}{r}0.3163^{* * *} \\
(0.047) \\
\end{array}$ \\
\hline \multicolumn{7}{|l|}{ Firm Financial } \\
\hline Return On Assets (ROA) & $\begin{array}{r}-0.0070 \\
(0.013)\end{array}$ & $\begin{array}{r}-0.0878 \\
(0.068)\end{array}$ & $\begin{array}{r}-0.1593 * * \\
(0.067)\end{array}$ & $\begin{array}{l}0.0528 \\
(0.033)\end{array}$ & $\begin{array}{r}0.4486^{* *} \\
(0.206)\end{array}$ & $\begin{array}{l}0.3034 \\
(0.237)\end{array}$ \\
\hline Operating Income Volatility & $\begin{array}{r}-0.0000 \\
(0.000)\end{array}$ & $\begin{array}{r}-0.0000 \\
(0.000)\end{array}$ & $\begin{array}{r}-0.0000^{*} \\
(0.000)\end{array}$ & $\begin{array}{l}0.0000 \\
(0.000)\end{array}$ & $\begin{array}{r}0.0000 * * \\
(0.000)\end{array}$ & $\begin{array}{l}0.0000 \\
(0.000)\end{array}$ \\
\hline Firm Size (Natural logarithm of total assets) & $\begin{array}{l}0.0023 \\
(0.003)\end{array}$ & $\begin{array}{l}0.0016 \\
(0.002)\end{array}$ & $\begin{array}{r}0.0029 * * * \\
(0.001)\end{array}$ & $\begin{array}{r}-0.0086 \\
(0.007)\end{array}$ & $\begin{array}{r}-0.0051 \\
(0.005)\end{array}$ & $\begin{array}{r}-0.0008 \\
(0.003)\end{array}$ \\
\hline Firm Beta & $\begin{array}{r}-0.0004 \\
(0.001)\end{array}$ & $\begin{array}{r}-0.0005 \\
(0.002)\end{array}$ & $\begin{array}{r}-0.0014 \\
(0.001)\end{array}$ & $\begin{array}{l}0.0049 \\
(0.007)\end{array}$ & $\begin{array}{l}0.0059 \\
(0.007)\end{array}$ & $\begin{array}{l}0.0030 \\
(0.009)\end{array}$ \\
\hline Tangibility (Total PPE / total assets) & $\begin{array}{l}0.0111 \\
(0.009)\end{array}$ & $\begin{array}{l}0.0088 \\
(0.008)\end{array}$ & $\begin{array}{l}0.0047 \\
(0.005)\end{array}$ & $\begin{array}{r}-0.0671^{* *} \\
(0.032)\end{array}$ & $\begin{array}{r}-0.0535^{* *} \\
(0.024)\end{array}$ & $\begin{array}{r}-0.1288^{* * *} \\
(0.020)\end{array}$ \\
\hline
\end{tabular}


Table A.3 - Instrumental variables regressions by investor heterogeneity (Cont.)

Robustness Analysis - Institutional Ownership by investor color

Perfect identified and over-identified IV systems

Dependent variable: institutional investor shares (shares)

\begin{tabular}{|c|c|c|c|c|c|c|}
\hline VARIABLES & $\begin{array}{c}m=0 \\
\text { RE-Grey } \\
\text { Col.1 }\end{array}$ & $\begin{array}{c}m=2 \\
\text { 2GLS-RE-Grey } \\
\text { Col.2 }\end{array}$ & $\begin{array}{c}\mathrm{m}=2 \\
\text { IV-Grey } \\
\text { Col.3 } \\
\end{array}$ & $\begin{array}{c}\mathrm{m}=0 \\
\mathrm{RE}-\mathrm{Ind} \\
\text { Col.4 }\end{array}$ & $\begin{array}{c}\mathrm{m}=2 \\
\text { 2GLS-RE-Ind } \\
\text { Col.5 } \\
\end{array}$ & $\begin{array}{c}\mathrm{m}=2 \\
\text { IV-Ind } \\
\text { Col.6 }\end{array}$ \\
\hline \multicolumn{7}{|l|}{ Board Variables } \\
\hline \multicolumn{7}{|l|}{ Market and Macro Variables } \\
\hline Turnover p75. (Dummy) & $\begin{array}{r}-0.0103^{*} \\
(0.005)\end{array}$ & $\begin{array}{r}-0.0109^{* * *} \\
(0.003)\end{array}$ & $\begin{array}{r}-0.0022 \\
(0.003)\end{array}$ & $\begin{array}{r}-0.0112 \\
(0.010)\end{array}$ & $\begin{array}{r}-0.0106 \\
(0.008)\end{array}$ & $\begin{array}{l}0.0030 \\
(0.009)\end{array}$ \\
\hline Property Rights & $\begin{array}{r}-0.0226 \\
(0.032)\end{array}$ & $\begin{array}{r}-0.0242 \\
(0.020)\end{array}$ & $\begin{array}{r}-0.0247 \\
(0.028)\end{array}$ & $\begin{array}{r}-0.0765 \\
(0.085)\end{array}$ & $\begin{array}{r}-0.0642 \\
(0.057)\end{array}$ & $\begin{array}{r}-0.1007 \\
(0.086)\end{array}$ \\
\hline m_embi & $\begin{array}{r}-0.0456 \\
(0.049)\end{array}$ & $\begin{array}{r}-0.0545^{* * *} \\
(0.018)\end{array}$ & $\begin{array}{r}-0.0587^{*} \\
(0.031)\end{array}$ & $\begin{array}{r}-0.0526 \\
(0.044)\end{array}$ & $\begin{array}{r}-0.0456 \\
(0.053)\end{array}$ & $\begin{array}{r}-0.1201 \\
(0.076)\end{array}$ \\
\hline Market Capitalization (\% of GDP) & $\begin{array}{r}-0.0000 \\
(0.000)\end{array}$ & $\begin{array}{r}-0.0001 \\
(0.000)\end{array}$ & $\begin{array}{r}-0.0001^{*} \\
(0.000)\end{array}$ & $\begin{array}{l}0.0001 \\
(0.000)\end{array}$ & $\begin{array}{l}0.0002 \\
(0.000)\end{array}$ & $\begin{array}{l}0.0001 \\
(0.000)\end{array}$ \\
\hline Constant & $\begin{array}{l}0.0249 \\
(0.045) \\
\end{array}$ & $\begin{array}{r}0.0470 \\
(0.029) \\
\end{array}$ & $\begin{array}{r}0.0499 * * \\
(0.021) \\
\end{array}$ & $\begin{array}{l}0.1332 \\
(0.101) \\
\end{array}$ & $\begin{array}{l}0.0205 \\
(0.101) \\
\end{array}$ & $\begin{array}{r}0.1942 * * * \\
(0.054) \\
\end{array}$ \\
\hline \multicolumn{7}{|l|}{ Regression Statistics } \\
\hline Observations & 3,563 & 3,519 & 3,519 & 3,563 & 3,519 & 3,519 \\
\hline Number of id_firm_n & 387 & 386 & $\ldots$ & 387 & 386 & $\ldots$ \\
\hline R2 & 0.0226 & 0.015 & 0.0175 & 0.097 & 0.0824 & 0.106 \\
\hline R2-between & 0.0411 & 0.0287 & $\ldots$ & 0.121 & 0.107 & ... \\
\hline R2-within & 0.021 & 0.0127 & $\ldots$ & 0.0543 & 0.0316 & ... \\
\hline Chi Stat & 34.22 & 83.02 & $\ldots$ & 92.32 & 230.5 & ... \\
\hline Chi2-p-value & 0.231 & {$[0.000]$} & $\ldots$ & {$[0.000]$} & {$[0.000]$} & $\ldots$ \\
\hline F Stat & $\ldots$ & $\ldots$ & 4.912 & $\ldots$ & $\ldots$ & 16.66 \\
\hline F stat $p$-value & $\ldots$ & $\ldots$ & {$[0.000]$} & $\ldots$ & $\ldots$ & [0.000] \\
\hline \multicolumn{7}{|l|}{ Test on Instruments } \\
\hline Hansen J-Test & & & 1.498 & & & 0.767 \\
\hline Hansen-p-value & & & [0.221] & & & [0.381] \\
\hline Endogeneity test & & & 5.076 & & & 1.724 \\
\hline Endog - $p$-Value & & & [0.0243] & & & [0.189] \\
\hline Underidentification & & & 66.88 & & & 66.88 \\
\hline Under-p-value & & & {$[0.000]$} & & & [0.000] \\
\hline $\begin{array}{l}\text { F Stat - 1st-stage } \\
\text { F-p-value }\end{array}$ & & & $\begin{array}{r}31.33 \\
{[0.000]}\end{array}$ & & & $\begin{array}{r}31.33 \\
{[0.000]}\end{array}$ \\
\hline
\end{tabular}

Notes: *** $\mathrm{p}<0.01, * * \mathrm{p}<0.05, * \mathrm{p}<0.1$

Robust standard errors in parentheses; $\mathrm{m}$ = the number of excluded instruments in the 2SLS; regressions include country and industry fixed effects. Instrumented Variable = ROA; Main Instruments: leverage ratio, growth opportunities and their first lags 


\section{Appendix 2 - The board characteristics dataset}

The board of directors' variables based on individual characteristics such as education, professional experience, number of simultaneous appointments, firm relationship status -i.e., outsider, independent-, age, gender and nationality are the central ones for this study. We follow corporate director heterogeneity definitions common found in board of directors studies from both agency and resource based reviewed in section 2 of the manuscript.

The starting point was to collect the list of director names by firm and appointment dates that was retrieved from Thomson One platform and complemented by personal biographies that were hand-collected, creating a directorfirm unbalanced panel. For many cases director public curriculum information were limited along with the presence of common names that made not possible to trace back all individual educational and professional characteristics as a balanced panel. Further, all biographies and professional information for each person is recorded at the retrieving year 2012, which does not affect individual time invariant characteristics such as gender or being a foreigner, but adds uncertainty for some time variant features such as professional experience at a given year.

The second step was the assembling of a director-firm-year panel. We started with an initial setting of boardyear panel that recorded the directorship for all members by year they were appointed. Then, we kept a director in a certain year, if she/he was appointed for at least half of that year. This is important to keep consistency with the size of the board, especially when there is a turnover of a board member and it would appear that more directors were participating in that year. Board conformation was corroborated with firm annual reports.

The third step is the transformation of the director-firm-year panel into a firm-year panel by adding the variables corresponding to each characteristic for all names per year in each one pf the selected firms in the dataset. For instance, if one observes that firm $i$ at year $t$ with a board size of 10 directors, 5 of them with CEO experience, 7 with master degree but 3 of them are MBAs, those records are added at firm-year level with the following board variables: 0.5 CEO-experience ratio, 0.7 with masters studies ratio and 0.3 masters in business studies ratio.

Table A.4 displays the basic structure of the director names raw datasets. Panel-A shows the director firm panel that includes the detail information for each individual. This dataset comprises 7,926 total directors where only 471 are women that is $4.6 \%$ of the sample. Directors with limited information are 1,544 or $21.1 \%$ of the sample. Panel-B depicts the expanded director-firm-year dataset that comprises more than 53,000 records. It keeps the panel structure by country, gender distribution and the weight of directors with limited information. Panel C summarizes the structure by country and length of the final dataset at board level -i.e., firm-year panel - that has the set of board members indicators by director heterogeneity. The final dataset has a maximum 5,180 firm-year observations for all board related variables. 
Table A4

Number of Directors raw datasets structure 2001 - 2012

Panel A. Director-Firm Panel composition

\begin{tabular}{lrrrrrr}
\hline & $\begin{array}{c}\text { Number of } \\
\text { Directors }\end{array}$ & Fraction & $\begin{array}{c}\text { Female } \\
\text { Directors }\end{array}$ & Fraction & $\begin{array}{c}\text { Directors with } \\
\text { limited } \\
\text { information }\end{array}$ & Fraction \\
\hline Argentina & 559 & 0.08 & 21 & 0.038 & 204 & 0.365 \\
Brazil & 2,191 & 0.30 & 213 & 0.097 & 346 & 0.158 \\
Chile & 1,496 & 0.21 & 55 & 0.037 & 440 & 0.294 \\
Colombia & 543 & 0.07 & 56 & 0.103 & 40 & 0.074 \\
Mexico & 1,375 & 0.19 & 62 & 0.045 & 312 & 0.227 \\
Peru & 1,132 & 0.16 & 64 & 0.057 & 202 & 0.178 \\
& & & & & & \\
Total & 7,296 & 1.00 & 471 & 0.065 & 1,544 & 0.212 \\
\hline
\end{tabular}

Panel B. Director-Firm-Year panel composition (Directorship level)

\begin{tabular}{lrrrrrr}
\hline & $\begin{array}{c}\text { Number of } \\
\text { Directorships }\end{array}$ & Fraction & $\begin{array}{c}\text { Female } \\
\text { Directors }\end{array}$ & Fraction & $\begin{array}{c}\text { Directorships } \\
\text { with limited } \\
\text { information }\end{array}$ & Fraction \\
\hline Argentina & 3,779 & 0.07 & 126 & 0.033 & 1,112 & 0.294 \\
Brazil & 16,199 & 0.31 & 1,745 & 0.108 & 2,512 & 0.155 \\
Chile & 11,260 & 0.21 & 350 & 0.031 & 3,308 & 0.294 \\
Colombia & 3,464 & 0.07 & 307 & 0.089 & 245 & 0.071 \\
Mexico & 11,393 & 0.21 & 455 & 0.040 & 2,416 & 0.212 \\
Peru & 7,012 & 0.13 & 342 & 0.049 & 1,041 & 0.148 \\
& & & & & & \\
Total & 53,107 & 1 & $3,325^{\circ}$ & 0.063 & 10,634 & 0.200 \\
\hline
\end{tabular}

Panel C. Firm-year panel length composition

\begin{tabular}{lrrrrrrr}
\hline & Argentina & Brazil & Chile & Colombia & Mexico & Peru & Total \\
\hline Obs & 356 & 1,501 & 1,233 & 408 & 762 & 920 & 5,180
\end{tabular}

Sources: Thomson One platform, personal biographies hand-collected retrieved mainly from companies annual reports, personal web pages, local regulators and LinkID

... end of document ... 